\title{
Effects of energy consumption of top 24 polluted countries on their GDP: New evidence based on natural resources and production of electricity
}

Rabnawaz Khan ${ }^{1 *}$ YuSheng Kong²

'School of Finance and Economics, Jiangsu University, Zhenjiang, Jiangsu, Zhenjiang 212013,

People's Republic of China.khan.rab@stmail.ujs.edu.cn

2Professor, Dean in the School of Finance and Economics, Jiangsu University, Zhenjiang 212013, People's Republic of China.1000001042@ujs.edu.cn

1 *Corresponding Author: khan.rab@stmail.ujs.edu.cn 


\begin{abstract}
:
Results of rapid economic growth, China, USA, and India have become the largest energy stealer and the greatest emitter of CO2 in the world and burn over $45 \%$ of global fuels in 2016. Meanwhile, the developing strategies of 24 polluted countries to decrease the energy consumption without additional economic output. This paper is exploring the effect of world top polluted countries C02 emission and their GDP and the production of electricity by energy indicators. The GLM model is not predict logistic and probit analysis directly; instead, it is mainly used for instinct to response of CO2 emission, using data for the period 19682017. The huge production of electricity will cause of abnormal CO2; this study offers true indication of exploring consumption of energy issues from the perspective of Granger casual and a positive unidirectional causality is detected between energy consumption to economic growth, while short-run bidirectional casualty exists among energy indicators.
\end{abstract}

Keyword: CO2 emission; energy consumption; production of Electricity; GDP 


\section{Introduction}

Fossil fuel: Petroleum fossil fuel, natural gas and coal have estimated at $80 \%$ of energy consumption in United States, and highest value recorded 101 quadrillion British thermal units (Btu) record only at 2018, which was $81(\mathrm{Btu})$ comparatively fossil fuel. Fossil fuel flow is driven by increases in natural gas consumption and petroleum in 2018, and the coal consumption fell by $4.3 \%$. In 2005 , USA consumption was in peaked and since then decline $42 \%$. The onset of petroleum, coal, renewable energy and nuclear power plant was major energy indicator of energy consumption in the USA in the period of $18^{\text {th }}$ to $21^{\text {st }}$ centuries. Additionally, the natural gas consumption was reached on turning point with value of 82.1 billion feet per day in 2018, only $37 \%$ consumption has been increased in last 8 to 10 years. In 2018, the petroleum product supplied is reached 20.5 million barrels per day relatively 2005. Fig-3 signifies the energy difference between production and consumption in the period of 2010-2016. The renewable energy consumption, which includes hydroelectricity, wind, biomas and solar was 11.4\% in 2018 its slightly quite less in 2017.

Highest populated country China coal production has increased ten-fold since than 1960 and a result of fossil-fuel CO2 emission more than doubled alone 2000. The China emission of CO2 have phenomenally increased in the period of 1950 to 1997 and the world largest emitter of CO2 due to fossil-fuel. It recorded annual $5.4 \%$ and rapidly growing with huge development. Furthermore, almost half of world cement produced in China 2008, it was 1.38 billion metric tons. Per capita emission rate now stand at 1.34 metric tons of carbon.(Boden et al. 2011, Etemad et al. 1991) China is the third largest natural gas consumption market and highly significant on the economic growth, comparatively other primary energy sources the natural gas has been optimal good choice to resource energy transition because it produces less $\underline{\mathrm{CO} 2}$ emissions. The annual natural gas consumption was $16.26 \%$ in 2000 to 2007 with $10.5 \%$ average annual economic growth (Fadiran et al. 2019, Li et al. 2019). China natural gas consumption was recorded at 27.381 Cub ft/Day bn in 2018 and it 1.17\% increased from 2017. The consumption of petroleum coke (CO2, N2O and $\mathrm{CH} 4$ ) in China is growing rapidly and increased by $18.9 \%$ from 2010 to 2016 . The petroleum relatedCO2, N2O and CH4 emissions reached 28, 143, and 870 million tonnes in 2016, respectively. (Shan et al. 2018, Xu et al. 2018)

China renewable energy is consisting on hydroelectric, solar power, wind power, biofuel, biomass and geothermal. In the field of electricity, China is one of the leading country in form of renewable energy sources and who produce comparatively double electricity from USA. In 2013, the country had produced $378 \mathrm{GW}$ of renewable power, namely from hydrochloric and wind power. Fig-3 signifies the energy difference between production and consumption in the period of 2010-2016.The renewable energy sector of China is growing faster than its fossil fuels and nuclear power. The largest rise of CO2 emissions grew 3\% in China since 2013. Hence, in 2013 to 2016, China CO2 emissions fell and shift away from smokestack industries, also renewable energy is source of booming power generation and implement policies to tackle air pollution. Furthermore, China started another construction boom by coal and increased $4.5 \%$ production in 2018 and 3.3. \% in 2017. With the world's largest population and fastest growing economy, China is far world's top one country from 25 highest $\mathrm{CO} 2$ emitters. The China $\mathrm{CO} 2$ emission is rapidly growing up cause of huge economic development. In 2017, the CO2 emission from fossil fuel was $46.44 \%$ and $74.92 \%$ higher from USA and India. Table 1. 
Fig 1:

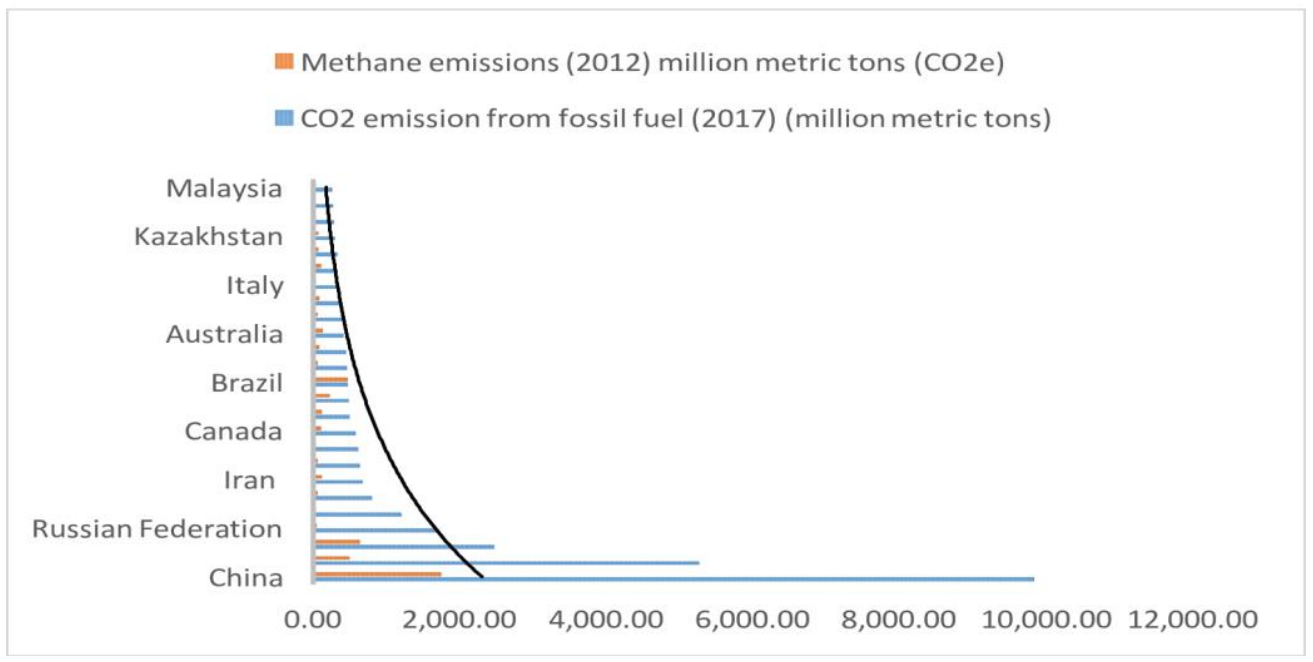

Figure 1: Highest CO2 emission

Carbon dioxide emission of India has increased from 7.1\% to 10.1\% in 2011 to 2014, which has been stemming from burning of fossil fuel and the cement manufacture. Overall growth of energy consumption will higher for future industries and economic development in India. The non-conventional sources of energy are reduced 11.8\% CO2 emission (Gupta et al. 1995, Kumar and Sinha 1995). The fourth largest country is Russia who contribute in CO2 emission after India and 14\% overall is recorded with $0.99 \mathrm{~kg}$ in 2010 (\$GDP). The Russian federation has been declared the level of greenhouse (GHG) emission by 20 to $30 \%$ in the period of 1990 to 2030. (Ketenci 2018, Pao and Tsai 2011)

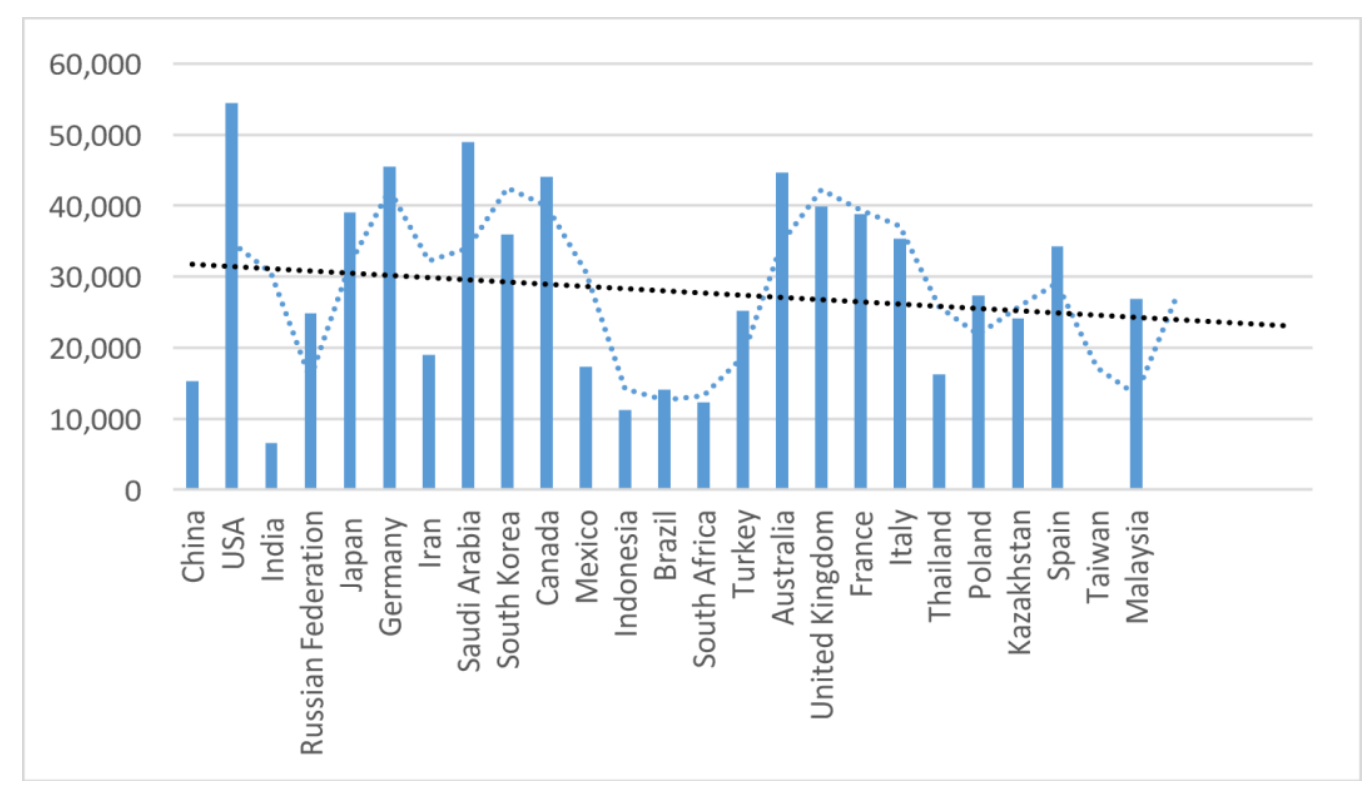

Figure 2: GDP per capita 2017 (\$) 
Table 1: 25 highest CO2 emitted countries

\section{Countries}

\begin{tabular}{l}
\hline China \\
\hline USA \\
\hline India \\
\hline Russian Federation \\
\hline Germany \\
\hline Iran \\
\hline Saudi Arabia \\
\hline South Korea \\
\hline Canada \\
\hline Mexico \\
\hline Indonesia \\
\hline Brazil \\
\hline South Africa \\
\hline Turkey \\
\hline Australia \\
\hline United Kingdom \\
\hline France \\
\hline Italy \\
\hline Thailand \\
\hline Poland \\
\hline Kazakhstan \\
\hline Spain \\
\hline Taiwan \\
\hline Malaysia \\
\hline
\end{tabular}

The world 15 top countries are responsible for $72 \% \mathrm{CO} 2$ emission and according to CEOWORLD magazine 25 countries ranked nations based on regional emission-CO2 emission from fossil fuel, methane emission, CO2 emission change-published in 2018 Global Carbon Project Table 1. This research paper is based on the explanation of rapid increase in $\mathrm{CO} 2$ emission by Petroleum, natural gas, coal, nuclear, biomas, other renewable energy and hydroelectric power, and its effects on GDP of top 24 polluted countries. Furthermore, the question raised on huge production of electricity by natural resources and results of $\mathrm{CO} 2$ emission. The question can be answered by important factor of $\mathrm{CO} 2$ emission change and individual territory economic development and to identify the force that changes emission.

Monetary term of economic data, Gross Domestic Product (GDP) and per capita of GDP used in early studies to compare energy intensity and not examine top 24 countries of high ranking $\mathrm{CO} 2$ emission by economic development. However, energy efficiency indicators are influenced by Petroleum, natural gas, coal, nuclear, Biomas, other renewable energy and hydroelectric with percapita of GDP, therefore, lead to misleading efficiency conclusions. If, such as the economic growth of 24 countries will increase, whereas energy use then economic efficiency indicator will rise although energy use per unit output, does not change.

Sources: Author compiling by the World's Top 25 countries $\mathrm{CO} 2$ Emission

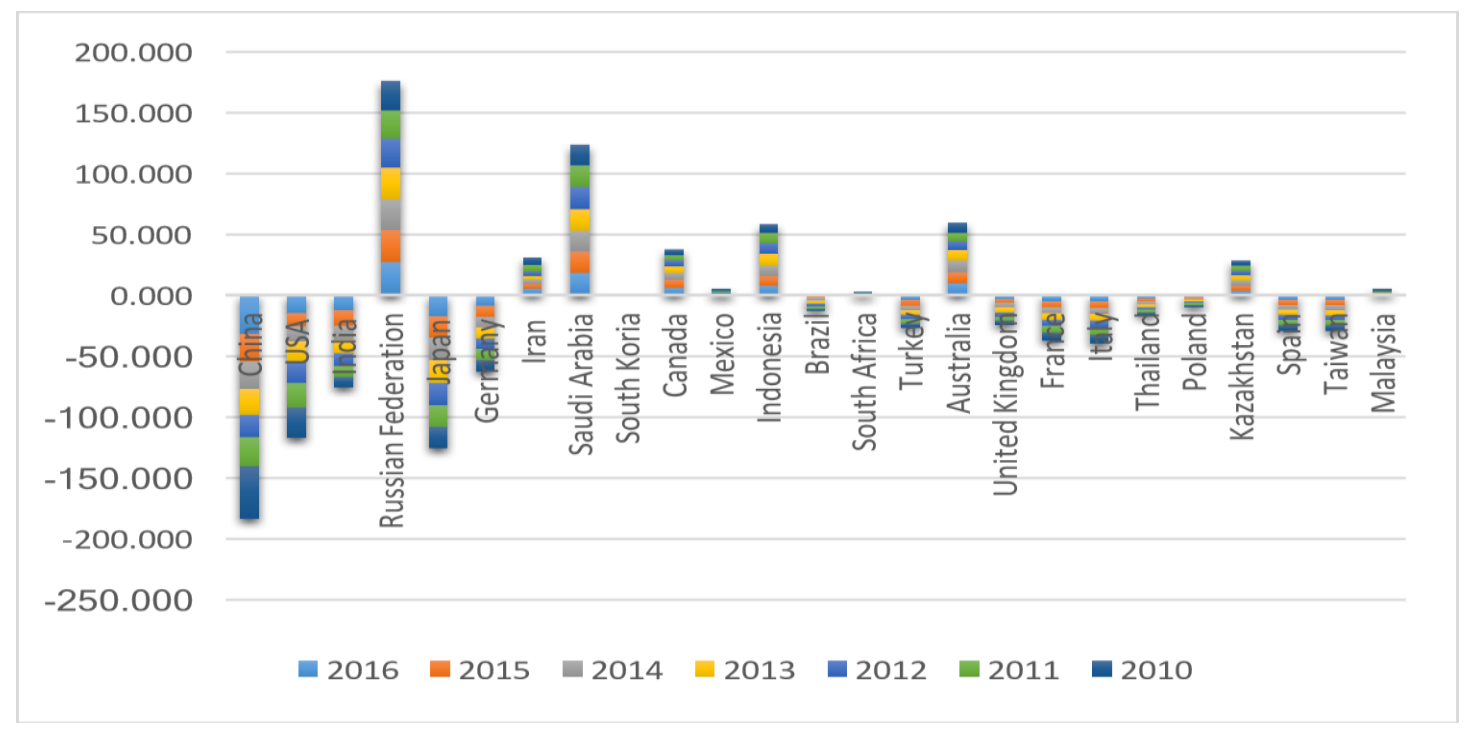

Figure 3: Difference b/w energy production and consumption. Source: US. Energy Information Admiration 
The economic growth of countries makes worse environment until it reaches to maximum level of growth, the peak of the Kuznets Curve, at which civilize people are making a free zone of $\mathrm{CO} 2$ for living. And using a more advance technology to reduce the impact of CO2 on the economic growth (Kong and Khan 2019). Further, if population and the poverty control by economic development policies, through its effect on rural and urban population for timber and fuel lead to increase in $\mathrm{CO} 2$ and therefore causes air pollution. By doing so, the possibility of a bias in result due to population and briskly economic growth are eliminated.(Baek 2017)

This study utilized the GLM method to identify the basic factors that contribute to changes in environment in 24 top polluted countries. Eight indicators Petroleum, natural gas, coal, nuclear, Biomas, other renewable energy and hydroelectric are examined with GDP per capita. The outline of this paper is as follows. After literature, $3^{\text {rd }}$ section is based on methodology, $4^{\text {th }}$ section is based on results and problems and the last section of research paper is indicated recommendation and conclusion of main findings.

\section{Literature review}

In the early studies, researchers examine the effects of $\mathrm{CO} 2$ emission by oil, gas and renewable energy of 79 different countries in the period of 1965-2017 but didn't classify the top 24 countries economic development and $\mathrm{CO} 2$ emission level by Petroleum, natural gas, coal, nuclear, Biomas, other renewable energy and hydroelectric.(Valadkhani et al. 2019a) We investigate how changes the primary energy production and consumption individually in panel data of 24 countries. The World Bank database are the reliable source of $\mathrm{CO} 2$ emissions has been employed in the current analysis. The effect of primary energy consumption has been elaborated the $\mathrm{CO} 2$ emission under optimal thresholds without nuclear and coal emission. And the energy consumption classifies on the bases of income and emission levels (Valadkhani et al. 2019b). The climate change policies have examined and results indicated transport carbon emission increased in top 7 countries. (Solaymani 2019). The EU-27 aggregated energy consumption with LMDI at 3 level and the researcher indicated the R\&D, efficiency technologies are main indicating elements of low CO2 emission (Fernández González et al. 2014). The BRICS countries results is analyzed the use of biomass energy consumption to sustainable environment and indicated energy dependency along rapid economic growth.(Aydin 2019) The 17 emerging countries is examined and results shows the change of economic growth and renewable energy consumption. The result show the conservation policies of energy do not have any adverse effect on economic development of 16 countries (Kong and Khan 2019) Some strengths of current analysis in earlier applications, are as follows 


\begin{tabular}{|c|c|c|c|c|c|}
\hline Countries & Study & Database & Econometric techniques & Periods & Outcomes \\
\hline China & $\begin{array}{l}\text { (Kang et al. } \\
\underline{2019} \underline{\text { Xu and }} \\
\underline{\text { Lin 2019, Xu }} \\
\underline{\text { et al. 2019) }}\end{array}$ & $\begin{array}{l}\text { International Energy } \\
\text { Agency (IEA) }\end{array}$ & $\begin{array}{l}\text { Non parametric } \\
\text { regression model, NARX } \\
\text { and VAR model. }\end{array}$ & $\begin{array}{l}2000-2015 \\
1965-2015 \\
2017-2050\end{array}$ & $\begin{array}{l}\text { Natural gas consumption has effect in the eastern region. } \\
\text { The coal consumption adds huge emissions. } \\
\text { Impact of } \mathrm{CO} 2 \text { on GDP and a positive shock to } \mathrm{CO} 2 \text {. }\end{array}$ \\
\hline USA & $\begin{array}{l}\text { (Chen et al. } \\
\text { 2019, Iiang et }\end{array}$ & $\begin{array}{l}\text { World Input-Output } \\
\text { Database (WIOD) }\end{array}$ & $\begin{array}{l}\text { Geographical Detector } \\
\text { Model }\end{array}$ & $1995-200$ & $\begin{array}{l}45 \% \text { global CO2 emission produced from China and } \\
\text { USA and production structure effect on environment. }\end{array}$ \\
\hline India & $\begin{array}{l}\text { (Anandarajah } \\
\text { and Gambhir }\end{array}$ & $\begin{array}{l}\text { The Energy Resources } \\
\text { Institute (TERI) }\end{array}$ & TIAM-UCL model & $2030-2050$ & $\begin{array}{l}34 \% \text { energy consumption by renewable energy and } 52 \% \\
\text { in } 2050\end{array}$ \\
\hline Russian & $\begin{array}{l}\text { (Cheng et al. } \\
\underline{\text { 2019) }}\end{array}$ & $\begin{array}{l}\text { Organization for Economic } \\
\text { Cooperation and } \\
\text { Development }(\mathrm{OECD})\end{array}$ & OLS regression & $2000-2012$ & $\begin{array}{l}\text { GDP has created negative impacts on } \mathrm{CO} 2 \text { emission in } \\
\text { EU- } 28 \text { countries. }\end{array}$ \\
\hline Japan & $\begin{array}{l}\text { (Cai et al. } \\
\underline{2018)}\end{array}$ & $\begin{array}{l}\text { World Development } \\
\text { Indicators (WDI) }\end{array}$ & ARDL & $1965-2015$ & As a dependent variable the integration exists in Japan \\
\hline Germany & $\begin{array}{l}\text { (González et } \\
\text { al. 2019) }\end{array}$ & EU-13 & Dynamic panel data & $1990-2105$ & $\begin{array}{l}\mathrm{CO} 2 \text { emission have been given positive implementation } \\
\text { to technological progress and changes. }\end{array}$ \\
\hline Iran & $\begin{array}{l}\text { (Hosseini et } \\
\underline{\text { al. 2019) }}\end{array}$ & WDI & $\begin{array}{l}\text { multiple linear } \\
\text { regression (MLR) }\end{array}$ & $1971-2014$ & $\begin{array}{l}\text { Iran include top CO2 emitted country and 30\% increase } \\
\text { in } 2030 .\end{array}$ \\
\hline Saudi Arabia & $\begin{array}{l}\text { Alkhathlan } \\
\text { and Javid }\end{array}$ & $\begin{array}{l}\text { BP Statistical Review of } \\
\text { World Energy }\end{array}$ & $\begin{array}{l}\text { Structural Time Series } \\
\text { Models (STSMs) }\end{array}$ & 1971-2013 & The CO2 emission grow by oil consumption \\
\hline South Korea & $\begin{array}{l}\text { (Jeong et al. } \\
\text { 2018) }\end{array}$ & $\begin{array}{l}\text { MFHC Multi-family } \\
\text { housing complex }\end{array}$ & Quartile & $\begin{array}{l}\mathrm{CO}_{2} \\
\text { emission } \\
\text { reduction } \\
\text { target by } \\
2030\end{array}$ & $\begin{array}{l}\text { The results indicated CO2 emission benchmark for } \\
\text { MFHCs can be applied. }\end{array}$ \\
\hline Canada & $\begin{array}{l}\text { (Cai et al. } \\
\underline{2018)}\end{array}$ & WDI & ARDL & $1970-2015$ & Canada use energy efficiency to reduce $\mathrm{CO} 2$ emission. \\
\hline
\end{tabular}

Sources: Author compiling by the literature of 10 top countries 


\section{Methodology}

\subsection{Generalized Liner Models (GLMs)}

GLM model is mainly to analysis that extended linear regression to non-linear systematic and non-normal stochastic components (McCullagh 1989). The purpose of establishing GLM model in this paper is not to predict logistic and probit analysis directly; instead, it is mainly used for instinct to response individually six (Energy, Natural Gas, Coal Rent, Nuclear Energy, Oil Gas and Coal, and Renewable Energy Consumption) groups of CO2 emission by different structure analysis. CO2 emission hypothesis, we followed the approach (Dong et al. 2018, Kang et al. 2019, Ohashi et al. 2017). The relationship between GDP, Energy, Natural Gas, Coal rent, Nuclear Energy Oil, Gas, Coal Renewable Energy consumption and Total population Eq 1 and GDPG Eq 2 are given as follows:

$$
G D P_{i t}=\alpha_{i t}+\gamma_{1 t}+\beta_{1 t} C O 2_{A_{i t}}+\beta_{2 t} C O 2_{B_{i t}}+\beta_{3 t} C O 2_{C_{i t}}+\beta_{4 t} T G G E_{i t}+\beta_{5 t} C O 2_{I N T_{i t}}+\beta_{6 t} C O 2_{-} F_{i t}+\beta_{7 t} P T_{i t}+\epsilon_{i t}
$$

$$
\begin{aligned}
& G D P G_{i t}=\alpha_{i t}+\gamma_{2 t}+\beta_{8 t} C O 2_{-} A_{i t}+\beta_{9 t} C O 2_{-} B_{i t}+\beta_{10 t} C O 2_{-} C_{i t}+\beta_{11 t} T G G E_{i t}+\beta_{12 t} C O 2_{-} I N T_{i t}+\beta_{13 t} C O 2_{-} F_{i t}+ \\
& \beta_{14 t} P T_{i t}+\epsilon_{i t}
\end{aligned}
$$

Where GDP and GDPG indicates the growth rate and growth rate per capita and $\mathrm{i}=1 \ldots . ., 50$ and $\mathrm{t}=1968, \ldots ., 2017$ divulge the country and time, respectively where the GDP and GDPG effects, which we take from the CO2 emission from Energy, Natural Gas, Coal Rent, Nuclear Energy, Oil Gas and Coal, and Renewable Energy Consumption. $\alpha_{i t}$ indicates country fixed effect and $\beta_{1 t}-\beta_{14 t}$ are parameters for elasticities in Eq 1 and Eq 2, which are indicating each explanatory variable of the panel $\epsilon_{i t}$, indicates estimated residual further in each group of variables. Furthermore, the research intention based on causal link between Energy, Natural Gas, Coal Rent, Nuclear Energy, Oil Gas and Coal, and Renewable Energy Consumption with GDP and GDPG. The GLM yield sturdy and useful tool to estimate in a regression and estimated variables are not sternly exogenous, autocorrelation and heteroscedasticity within exist. (Chong et al. 2019, Hosseini et al. 2019). The GLM is applied on individual group to analyze the impact of explanatory variable in each group on $\mathrm{CO} 2$ emission.

The Energy consumption is analyzed by energy use and natural resources Eq 3a-3d. and cause of CO2 emission. Natural gas consumption is analyzed by production of electricity and natural gas Eq 4a-4d. and cause of $\mathrm{CO} 2$ emission. Coal rent consumption is analyzed by production of electricity and coal rents with causes of $\mathrm{CO} 2$ from solid fuel Eq 5a-5d. Nuclear energy consumption is analyzed by production of electricity of nuclear resources and nuclear energy with causes of green gas emission Eq 6a-6d. Oil gas and coal consumption is examined by electricity access and production of electricity from oil gas and coal with causes of intensity of CO2 Eq 7a-7d. Renewable energy consumption is analyzed by renewable and waste combustion and net saving includes emission damages with causes of CO2 from manufacturing industries Eq 8a-8d. 


\section{Group 1: Energy consumption}

CO2_A $A_{i t}=a_{i t}+\mu_{1 t}+\eta_{1 t} E G_{i t}+\eta_{2 t} A N R D_{i t}+\partial i t$

$\Delta C O 2_{-} A_{i t}=a_{1 s}+\sum_{k=1}^{q} \mu_{1 i k} \Delta C O 2_{-} A_{i t-k}+\sum_{k=1}^{q} \mu_{2 i k} \Delta E G_{i t-k}+\sum_{k=1}^{q} \mu_{3 i k} \Delta A N R D_{i t-k}+\vartheta_{1 i} \varepsilon_{t-k}+\tau_{1 i}$

$\Delta E G_{i t}=a_{2 s}+\sum_{k=1}^{q} \mu_{4 i k} \Delta C O 2 A_{i t-k}+\sum_{k=1}^{q} \mu_{5 i k} \Delta E G_{i t-k}+\sum_{k=1}^{q} \mu_{6 i k} \Delta A N R D_{i t-k}+\vartheta_{2 i} \varepsilon_{t-k}+\tau_{2 i}$

$\Delta A N R D_{i t}=a_{3 s}+\sum_{k=1}^{q} \mu_{7 i k} \Delta C O 2 \_A_{i t-k}+\sum_{k=1}^{q} \mu_{8 i k} \Delta E G_{i t-k}+\sum_{k=1}^{q} \mu_{9 i k} \Delta A N R D_{i t-k}+\vartheta_{3 i} \varepsilon_{t-k}+\tau_{3 i}$

\section{Group 2: Natural gas consumption}

$C O 2_{-} B_{i t}=a_{i t}+\mu_{2 t}+\eta_{3 t} E P N G_{i t}+\eta_{4 t} N G R_{i t}+\partial i t$

$\triangle C O 2_{-} B_{i t}=a_{4 s}+\sum_{k=1}^{q} \mu_{10 i k} \Delta C O 2_{-} B_{i t-k}+\sum_{k=1}^{q} \mu_{11 i k} \Delta E P N G_{i t-k}+\sum_{k=1}^{q} \mu_{12 i k} \Delta A N G R_{i t-k}+\vartheta_{2 i} \varepsilon_{t-k}+\tau_{4 i}$

$\Delta E P N G_{i t}=a_{5 s}+\sum_{k=1}^{q} \mu_{13 i k} \Delta C O 2_{-} B_{i t-k}+\sum_{k=1}^{q} \mu_{14 i k} \Delta E P N G_{i t-k}+\sum_{k=1}^{q} \mu_{15 i k} \Delta A N G R_{i t-k}+\vartheta_{2 i} \varepsilon_{t-k}+\tau_{5 i}$

$(4 \mathrm{c})$

$\Delta A N G R_{i t}=a_{6 s}+\sum_{k=1}^{q} \mu_{16 i k} \Delta C O 2_{-} A_{i t-k}+\sum_{k=1}^{q} \mu_{17 i k} \Delta E G_{i t-k}+\sum_{k=1}^{q} \mu_{18 i k} \Delta A N G R_{i t-k}+\vartheta_{3 i} \varepsilon_{t-k}+\tau_{6 i}$

\section{Group 3: Coal rent consumption}

CO2_C $C_{i t}=a_{i t}+\mu_{3 t}+\eta_{5 t} E P C S_{i t}+\eta_{6 t} C R_{i t}+\partial i t$

$\triangle C O 2_{-} C_{i t}=a_{2 s}+\sum_{k=1}^{q} \mu_{10 i k} \Delta C O 2_{-} B_{i t-k}+\sum_{k=1}^{q} \mu_{11 i k} \Delta E P N G_{i t-k}+\sum_{k=1}^{q} \mu_{12 i k} \Delta A N G R_{i t-k}+\vartheta_{2 i} \varepsilon_{t-k}+\tau_{7 i}$

$\Delta E P N G_{i t}=a_{3 s}+\sum_{k=1}^{q} \mu_{13 i k} \Delta C O 2_{-} B_{i t-k}+\sum_{k=1}^{q} \mu_{14 i k} \Delta E P N G_{i t-k}+\sum_{k=1}^{q} \mu_{15 i k} \Delta A N G R_{i t-k}+\vartheta_{2 i} \varepsilon_{t-k}+\tau_{8 i}$

$\Delta A N G R_{i t}=a_{3 s}+\sum_{k=1}^{q} \mu_{16 i k} \Delta C O 2_{-} A_{i t-k}+\sum_{k=1}^{q} \mu_{17 i k} \Delta E G_{i t-k}+\sum_{k=1}^{q} \mu_{18 i k} \Delta A N G R_{i t-k}+\vartheta_{3 i} \varepsilon_{t-k}+\tau_{9 i}$

\section{Group 4: Nuclear energy consumption}

$T G G E_{i t}=a_{i t}+\mu_{4 t}+\eta_{7 t} E P N S_{i t}+\eta_{8 t} A N E_{i t}+\partial i t$

$\Delta T G G E_{i t}=a_{2 s}+\sum_{k=1}^{q} \mu_{19 i k} \Delta T G G E_{i t-k}+\sum_{k=1}^{q} \mu_{20 i k} \Delta E P N S_{i t-k}+\sum_{k=1}^{q} \mu_{21 i k} \Delta A N E_{i t-k}+\vartheta_{2 i} \varepsilon_{t-k}+\tau_{10 i}$

$\Delta E P N S_{i t}=a_{2 s}+\sum_{k=1}^{q} \mu_{22 i k} \Delta T G G E_{i t-k}+\sum_{k=1}^{q} \mu_{23 i k} \Delta E P N S_{i t-k}+\sum_{k=1}^{q} \mu_{24 i k} \Delta A N E_{i t-k}+\vartheta_{2 i} \varepsilon_{t-k}+\tau_{11 i}$

$\Delta A N E_{i t}=a_{2 s}+\sum_{k=1}^{q} \mu_{25 i k} \Delta T G G E_{i t-k}+\sum_{k=1}^{q} \mu_{26 i k} \Delta E P N S_{i t-k}+\sum_{k=1}^{q} \mu_{27 i k} \Delta A N E_{i t-k}+\vartheta_{2 i} \varepsilon_{t-k}+\tau_{12 i}$

\section{Group 5: Oil, Gas and Coal consumption}

CO2_INT $i t=a_{i t}+\mu_{5 t}+\eta_{9 t} A E_{i t}+\eta_{10 t} E$ POGC $C_{i t}+\partial i t$

$\Delta C O 2_{-} I N T_{i t}=a_{2 s}+\sum_{k=1}^{q} \mu_{28 i k} \Delta C O 2_{-} I N T_{i t-k}+\sum_{k=1}^{q} \mu_{29 i k} \Delta A E_{i t-k}+\sum_{k=1}^{q} \mu_{30 i k} \Delta E P O G C_{i t-k}+\vartheta_{2 i} \varepsilon_{t-k}+\tau_{13 i}$

$\Delta A E_{i t}=a_{2 s}+\sum_{k=1}^{q} \mu_{31 i k} \Delta C O 2_{-} I N T_{i t-k}+\sum_{k=1}^{q} \mu_{32 i k} \Delta A E_{i t-k}+\sum_{k=1}^{q} \mu_{33 i k} \Delta E P O G C_{i t-k}+\vartheta_{2 i} \varepsilon_{t-k}+\tau_{14 i}$

$\triangle E P O G C_{i t}=a_{2 s}+\sum_{k=1}^{q} \mu_{34 i k} \Delta C O 2_{-} I N T_{i t-k}+\sum_{k=1}^{q} \mu_{35 i k} \Delta A E_{i t-k}+\sum_{k=1}^{q} \mu_{36 i k} \Delta E P O G C_{i t-k}+\vartheta_{2 i} \varepsilon_{t-k}+\tau_{15 i}$ 
Group 6: Renewable Energy consumption

CO2_F $F_{i t}=a_{i t}+\mu_{6 t}+\eta_{11 t} C R W_{i t}+\eta_{12 t} A N S E_{i t}+\partial i t$

$\Delta C O 2_{-} F_{i t}=a_{2 s}+\sum_{k=1}^{q} \mu_{36 i k} \Delta C O 2_{-} F_{i t-k}+\sum_{k=1}^{q} \mu_{37 i k} \Delta C R W_{i t-k}+\sum_{k=1}^{q} \mu_{38 i k} \Delta A N S E_{i t-k}+\vartheta_{2 i} \varepsilon_{t-k}+\tau_{16 i}$

$\Delta C R W_{i t}=a_{2 s}+\sum_{k=1}^{q} \mu_{39 i k} \Delta C O 2_{-} F_{i t-k}+\sum_{k=1}^{q} \mu_{40 i k} \Delta C R W_{i t-k}+\sum_{k=1}^{q} \mu_{41 i k} \Delta A N S E_{i t-k}+\vartheta_{2 i} \varepsilon_{t-k}+\tau_{17 i}$

$\Delta A N S E_{i t}=a_{2 s}+\sum_{k=1}^{q} \mu_{42 i k} \Delta C O 2_{-} F_{i t-k}+\sum_{k=1}^{q} \mu_{43 i k} \Delta C R W_{i t-k}+\sum_{k=1}^{q} \mu_{44 i k} \Delta A N S E_{i t-k}+\vartheta_{2 i} \varepsilon_{t-k}+\tau_{18 i}$

Where $\mathrm{i}=1 \ldots, 50$ and $\mathrm{t}=1968, \ldots ., 2017$ for all above six groups in panel data of each country. Alongside, the parameter $a_{i}$ and $\mu_{t}$ are identified effect with deterministic trend. It is estimated by Engle Granger Table 4, longterm model, indicated in Eq 3a-8d is assessed one period lagged. Furthermore, all above six groups Granger with F-test individually among them. Where the first difference specifies by $\Delta$, as lag of length indicated by $q$ at one conferring to likehood ratio-test, and $\tau$ indicate uncorrelated serial error term.

\subsection{Source of data and description}

This paper investigates into the relationship of $\mathrm{CO} 2$ in six groups individually. Additionally, the economic growth and per-captia indicates the dynamic relationship with CO2_A, CO2_B, CO2_C, TGGE, CO2_INT and CO2_F. The level of CO2 emission is analyzed, and its effects on GDP of top 24 polluted countries with huge production of electricity by natural resources in the period of 1968-2017 are selected as the research samples Table 3. Research variables are erected as follow with the meaningful statistics tools in Table 4. 
Table 3: Variables descriptions

\begin{tabular}{|c|c|c|c|}
\hline Variables & Symbol & Description & Data Source \\
\hline Natural resources & ANRD & Natural resource depletion and mineral depletion & NY.ADJ.DRES.GN. ZS \\
\hline Energy use & EG & Primary energy before transformation & EG.USE.PCAP.KG. OE \\
\hline Energy consumption & CO2_A & $\begin{array}{l}\mathrm{C} 02 \text { produced during consumption of solid, } \\
\text { liquid and gas }\end{array}$ & EN.ATM.CO2E.KT \\
\hline Natural gas & NGR & Natural gas rents and total costs of production & NY.GDP.NGAS. RT. ZS \\
\hline Production of electricity from natural gas & EPNG & Electricity sources and natural gas & EG.ELC.NGAS.ZS \\
\hline Natural gas consumption & CO2_B & CO2 emission from liquid fuel consumption & EN.ATM.CO2E.GF. KT \\
\hline Coal rents & $\mathrm{CR}$ & Coal rent value and their costs of production. & NY.GDP.COAL. RT. ZS \\
\hline Production of electricity from coal sources & EPCS & Sources of electricity used to generate electricity & EG.ELC.COAL. ZS \\
\hline Carbon emission from solid fuel & CO2_C & CO2 emissions from consumption of solid fuel & EN.ATM.CO2E.SF. KT \\
\hline Nuclear Energy & ANE & $\begin{array}{l}\text { Non carbohydrate energy does not produce } \mathrm{CO} 2 \text {, } \\
\text { when generated }\end{array}$ & EG.USE.COMM.CL. ZS \\
\hline Production of electricity from nuclear sources & EPNS & Electricity produced by nuclear power plants & EG.ELC.NUCL. ZS \\
\hline Greenhouse gas emission & TGGE & CO2 excluding burning of short cycle biomass & EN.ATM.GHGT. KT. CE \\
\hline $\begin{array}{l}\text { Production of electricity from oil, gas, and coal } \\
\text { sources }\end{array}$ & EPOGC & Oil, gas and liquids is source of electricity & EG.ELC.FOSL. ZS \\
\hline Electricity access & $\mathrm{AE}$ & Electrification data collected from industries & EG.ELC.ACCS. ZS \\
\hline Intensity of Carbon dioxide & CO2_INT & $\mathrm{CO} 2$ emission from use of coal as source of energy & EN.ATM.CO2E.EG. ZS \\
\hline Net saving includes emission damages & ANSE & $\begin{array}{l}\text { Natural savings and particular emissions } \\
\text { damage. }\end{array}$ & NY.ADJ.SVNG.GN. ZS \\
\hline Renewable and waste combustion & CRW & $\begin{array}{l}\text { Combustible renewables as percentage of energy } \\
\text { use }\end{array}$ & EG.USE.CRNW. ZS \\
\hline Carbon emission from manufacturing industries & CO2_F & $\mathrm{CO} 2$ emissions from combustion of fuels industry & EN.CO2.MANF. ZS \\
\hline Total population & PT & De facto population & SP.POP.TOTL \\
\hline Growth of domestic product & GDP & Annual percentage growth on local currency & NY.GDP.MKTP.KD. ZG \\
\hline Per-capita growth (GDP) & GDPG & Annual percentage growth rate of GDP & NY.GDP.PCAP.KD. ZG \\
\hline
\end{tabular}

Sources: Selection based on accessibility of database. Variable's definition indicated in Table 3 
Table 4: Descriptive statistics

\begin{tabular}{|c|c|c|c|c|c|}
\hline \multicolumn{2}{|c|}{ Descriptive analysis } & \multirow{2}{*}{\begin{tabular}{|l|} 
Mean \\
\end{tabular}} & \multirow{2}{*}{$\begin{array}{ll}\text { Median } & \\
& 1.236\end{array}$} & \multirow{2}{*}{$\begin{array}{l}\text { Std. Dev. } \\
\end{array}$} & \multirow{2}{*}{$\begin{array}{r}\text { Observations } \\
1030\end{array}$} \\
\hline Energy consumption & ANRD & & & & \\
\hline & CO2_A & 754203.900 & 346876.200 & 1336399.000 & 1021 \\
\hline \multirow{2}{*}{ Natural gas consumption } & EPNG & 16.525 & 8.180 & 20.226 & 1071 \\
\hline & CO2_B & 121734.000 & 46985.270 & 248984.800 & 1021 \\
\hline $\begin{array}{c}\text { Coal rent } \\
\text { consumption Coal rent } \\
\text { consumption }\end{array}$ & CR & 0.411 & 0.048 & 0.901 & 1028 \\
\hline \multirow{3}{*}{$\begin{array}{c}\text { Nuclear energy } \\
\text { consumption }\end{array}$} & ANE & 6.312 & 2.941 & 8.429 & 1058 \\
\hline & EPNS & 8.005 & 0.316 & 14.958 & 1059 \\
\hline & TGGE & 1160331.000 & 550135.800 & 1649953.000 & 997 \\
\hline \multirow{2}{*}{$\begin{array}{l}\text { Oil, Gas and Coal } \\
\text { consumption }\end{array}$} & EPOGC & 68.787 & 75.064 & 24.639 & 1071 \\
\hline & AE & 95.263 & 100.000 & 12.024 & 559 \\
\hline \multirow[t]{3}{*}{ GDP effects } & PT & 153000000.000 & 57000451.000 & 281000000.000 & 1195 \\
\hline & GDP & 3.846 & 3.707 & 4.809 & 1075 \\
\hline & GDPG & 2.483 & 2.544 & 4.602 & 1075 \\
\hline
\end{tabular}

Sources: Reckoning by authors. Variable's definition indicated in Table 3 . 


\section{Empirical estimation results and discussions}

Table 1, indicates the Energy, Natural Gas, Coal rent, Nuclear Energy Oil, Gas and Coal Renewable Energy consumption, variables mean in the period of 1968-2017, and countries analyzed by the type of CO2 emission individually. In each group CO2_A, CO2_B, CO2_C, TGGE, CO2_INT and CO2_F have been statistically tested individual with explanatory variables. The descriptive statistics test is applied to judge whether the explanatory variable in each group individually employed with response variables. The China (CO2_C), USA (CO2_A, CO2_B, TGGE), Saudi Arabia (CO2_INT) and Korea (CO2_F) are indicated the highest mean value Fig 1 While, Korea, Malaysia, Indonesia (CO2_A, CO_B), Iran Islamic Republic, Malaysia, Mexico (C02_C, TGGE), Indonesia, Brazil and Russian Federation (CO2_F) register the lowest mean. The highest mean value concludes that all predictor with CO2_A, CO2_B, CO2_C, TGGE, and CO_F is integrated countries economic development. Table 7 indicate the correlation, relationship between carbon emission and selected instrumental variables, emanation such as CO2_A, CO2_B, CO2_C, TGGE, and CO_F were noticed. The results computed by Generalized Linear Model (GLM) and in order to remove inconvenience, consider stationary test by $1^{\text {st }}$ generation unit root test and individual intercept in level. The most of statistics test is reject the null hypothesis, including the variables are stationary at level in individual groups.

\subsection{Unit root and co-integration}

Before statistically analysis, the unit root test is applied by ADF, PP, LLC, IPS and BR whether the variables in group A (ANRD, EG, CO2_A), group B (NGR, EPNG, CO2_B), group C (CR, EPCS, CO2_C), group D (ANE, EPNS, TGGE), group E (EPOGC, AE, CO2_INT), group F (ANSE, CRW, CO2_F) and group G (PT, GDP, GDPG) have unit-root or not. Most of statistically test rejected the null hypothesis, including the selected variables are stationary at level and in the same order variables are tested, whether the co-integration exist among the variables or not. In $1^{\text {st }}$ step VAR is estimated and model prove to be stable Table 5. Furthermore, all the six group variables are tested by co-integration methods reject the null hypothesis and there is no co-integration relationship among variables. (Kao C 1995, P. 2004).

\subsection{Pairwise Granger causality test}

Granger causality test is applied for confirm whether an endogenous treated as exogenous in individual groups. Ahead, selected variables are co-integrated, a panel Vector Error Correlation (VEC) is assessed in order to perform Granger Causality Test (GCT) among variables Table 6. Additionally, we cull the null hypothesis that CO2_A does not granger cause EG and ANRD and EG does not granger cause of ANRD and vice versa found in Energy consumption.

In the Natural Gas, Coal rent, Nuclear Energy Oil, Gas and Coal Renewable Energy consumption, CO2_B, CO2_C, TGGE, CO2_INT and CO2_F does not granger cause of EPNG, EPCS, TGGE, EPOGC and CRW. (Emirmahmutoglu and Kose 2011, Hao et al. 2018, Pao and Tsai 2011). It is remarkable that though an excessive number of researcher examining the relationship of energy consumption with economic growth, very few on the group consumptions. Moreover, a consent has not been made China energy consumption between economic development. USA and India $2^{\text {nd }}$ highest level of energy consumption cause of economic changes, the panel data of 24 top polluted countries examine in the six different groups of consumption. In contrast literature examined unidirectional causality running from output to Energy, Natural Gas, Coal rent, Nuclear Energy Oil, Gas and Coal Renewable Energy consumption (Cheng et al. 2017 Herrerias et al. 2013, Liang et al. 2019, Lin et al. 2018, McGee and Greiner 2019, Wolde-Rufael and Menyah 2010). It should also be noted that many countries except China, still user of bulky of natural resources, Natural gas, Coal rent, Nuclear energy and renewable energy in different group consumption. The offered literature has already inveterate that the use of coal rent, natural gas, nuclear energy and renewable energy would impede economic development (Dong et al. 2019, in and Kim 2018). 
Natural gas to electricity causality and vice versa found (Uribe et al. 2018). USA and China play important role to production of electricity by Coal and is a crucial factor for economic growth (Morales Pedraza 2019, Wang et al. 2019). The USA provided substantial electricity by Nuclear power and economically meaningful increase in capacity of production (Karney 2019). The production of electricity by different fuel sources (oil, coal and water) and prices of coal and oil are similar, found in the in the long run (Kharbach and Chfadi 2018).

The results of estimation may be the reason of Granger causality for Natural Gas, Coal rent, Nuclear Energy Oil, Gas and Coal Renewable Energy consumption. The conclusion that ANRD, EG, NGR, EPNG, CR, EPCS, ANE, EPNS, EPOGC, AE, ANSE and CRW are not a Granger cause of CO2_A, CO2_B, CO2_C, TGGE, CO2_INT and $\mathrm{CO} 2$ F $\mathrm{F}$ differs from the earlier study, some prior research using mass of macro data, as most of earlier research found positive effect on ANRD, CR, EPCS and ANSE on CO2_A, CO2_B, CO2_C (Acheampong 2018, Mezghani and Ben Haddad 2017). However, one possible reason for disparity may be that this study emphases on the $\underline{25}$ polluted countries except Taiwan, while the majority of previous study have already discussed the environmental causes of GDP but this study determined the six different groups of emission and individual effect of each variable with CO2_A, CO2_B, CO2_C, TGGE, CO2_INT and CO2_F.

Moreover, the Granger causality existence from energy consumption to ANRD, EG, NGR, EPNG, CR, EPCS, ANE, EPNS, EPOGC, AE, ANSE and CRW specifies that the level of growth. Energy consumption precedes to increase of ANRD, EG, NGR, EPNG, CR, EPCS, ANE, EPNS, EPOGC, AE, ANSE and CRW in 24 top polluted countries, which can be assumed as a feature of individual country economic growth. There is a caution that the co-existent casualty in the coherent might not be occur though the calculated results, it suggests that the presence of Granger causality. Test results is indicated significant causality among the variables. Almost, a uni-directional casualty could run from energy consumption and its effected on GDP. In fact, however, if CO2_A, CO2_B, CO2_C, TGGE, CO2_INT and CO2_F is mismanaged into barren economic sectors, then economic growth of individual state valor be insignificant or fail to occur at all and create big problems for nations.

\subsection{Particular analysis by GLM}

After computation of the Granger causality among the variables, specify the relationship and it is needed by Generalized Linear Model (GLM), that linear regression to permit non-linear systematic components with non-

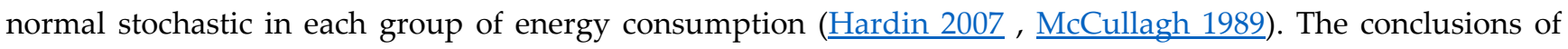
covariance of GLM by GDP are obtained presented in following Table 3. The covariance of reliant variables is estimated with GDPG in Ordinary and Huber-White. It can be observed that CO2_A, CO2_B, CO2_C, TGGE, CO2_INT and CO2_F positively effect GDPG at the significant level of $1 \%$ in the long term and that $1 \%$ increase in energy consumption CO2_A, will cause of GDPG increase with a 2.238. Additionally, a 1\% increase in CO2_B, CO2_C, TGGE, CO2_INT and CO2_F will cause a 0.436, 2.277,2.435 and 2.953 increase in GDPG. The impact of CO2_A, CO2_B, CO2_C, TGGE, CO2_INT, CO2_F and GDPG is also positive at significant level of $1 \%$ and $1 \%$ rise is related to an increase in the GDPG results Table 3. The individual state consumption is stated in Figure 4. Furthermore, the group covariance individually computed with Wald test. The impact of CO2_A, TGGE and CO2_INT is indicating negative significant level of 1\% in ANRD, ANE and AE with 11.248, 3.145 and 0.913 Wald test.

\subsection{Additional analysis}

The above analysis implies the influence of each group and employed on the other variables. Conversely, the result does not specify the 10 years' period of Energy, Natural gas, Coal rent, Nuclear energy, Oil gas and Coal, and Renewable energy consumption. Furthermore, the stepwise regression, indicate five periods and each period is consisted 10 years 'duration Table 7. 
CO2_A

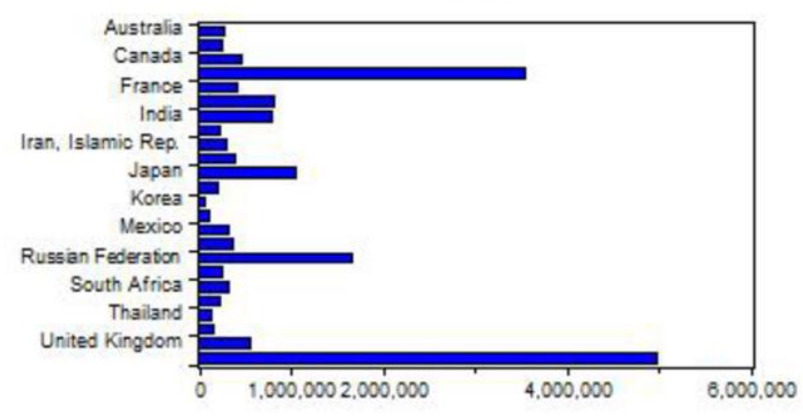

$\mathrm{CO}_{-} \mathrm{C}$

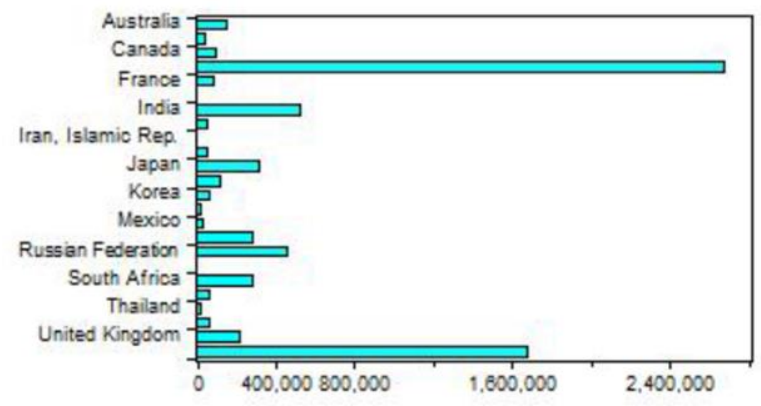

CO2_INT

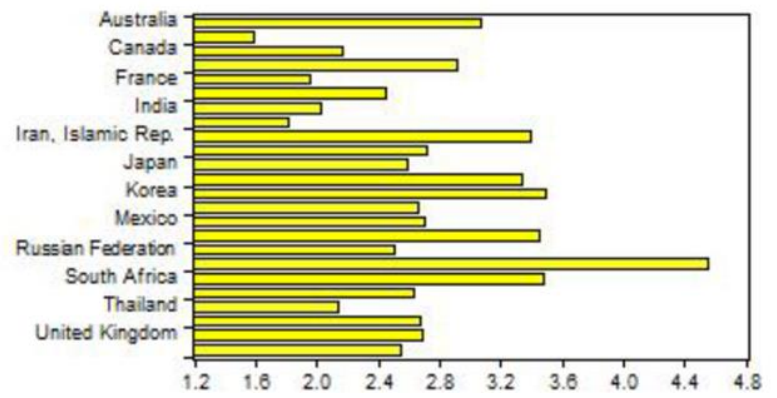

CO2_B

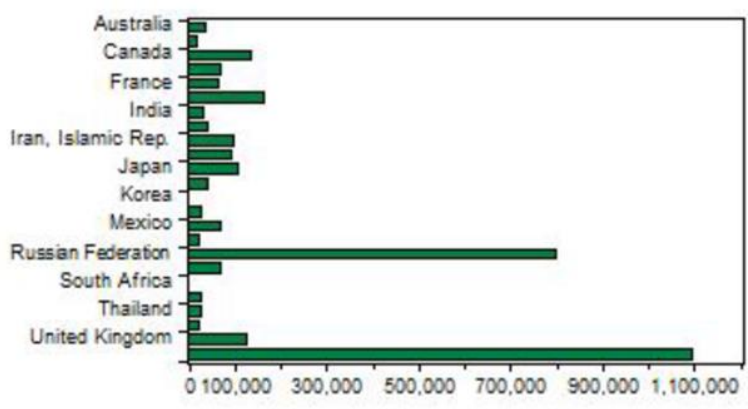

TGGE

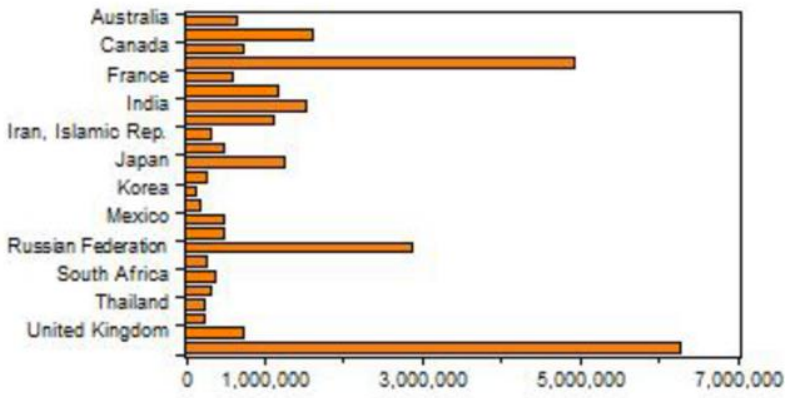

$\mathrm{CO}_{-} \mathrm{F}$

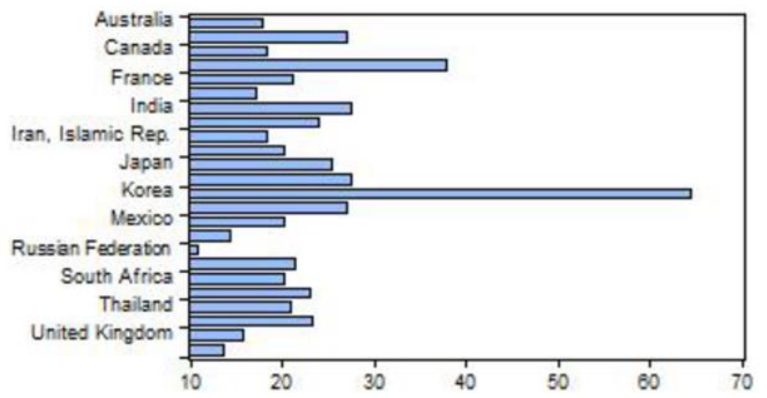

Figure 4: Countries distribution by mean 


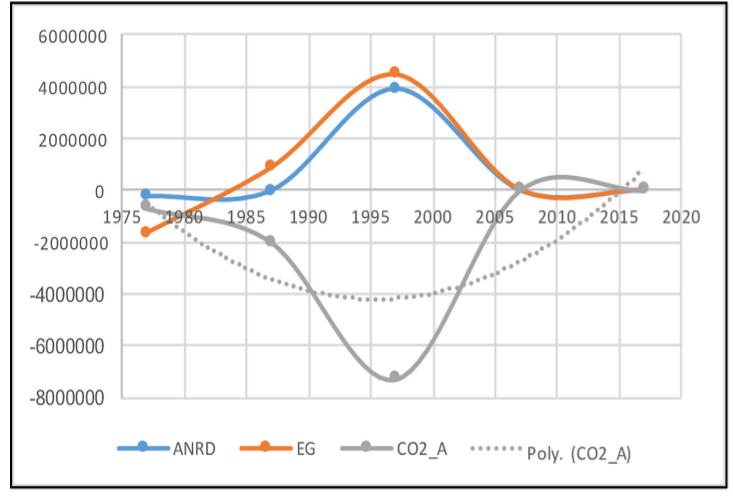

China consumption

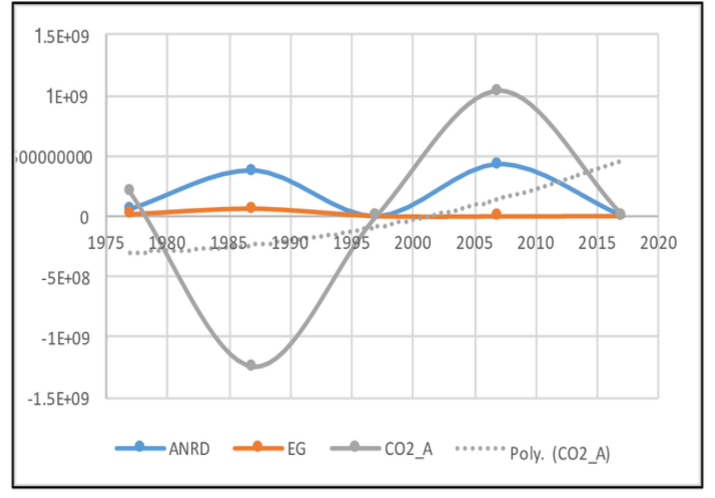

USA consumption

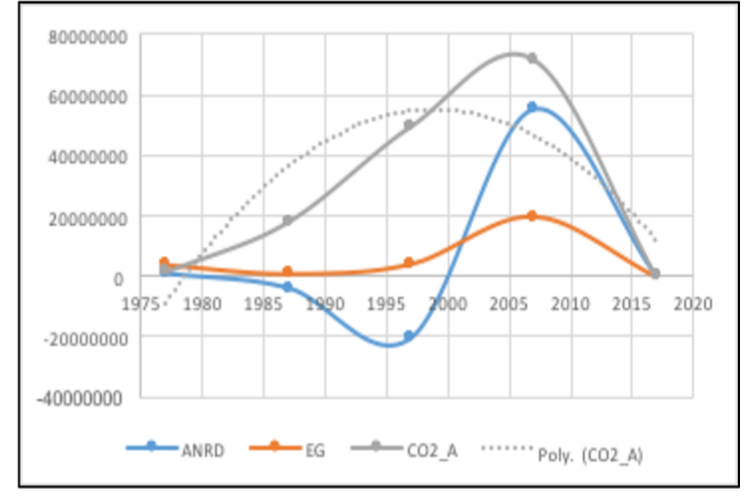

India consumption

Figure 5: High level of consumption

The $1^{\text {st }}$ period of Energy consumption is indicated negative at significant level of 1\% and employ that $1 \%$ increase CO2_A is related to decrease $1 \%$ in ANRD and EG. In the Natural gas consumption $1^{\text {st }}$ and $3^{\text {rd }}$ periods are specified negative at significant level and $1 \%$ increase in CO2_B is related to decrease NGR and EPNG. However, $4^{\text {th }}$ and $5^{\text {th }}$ period is specified positive at the significant level of $1 \%$ that a $1 \%$ rise in CO2_A, CO2_B, CO2_C, TGGE, CO2_INT and CO2_F are employed that 1\% used of ANRD, NGR, EPNG, CR, EPCS, and ANE. The estimated results are influence of a shock of specific periods on group of the variables. This paper utilizes individual states energy consumption and their impact, computation of results shown in Fig 5 and Fig 6 with high and low level of consumption.

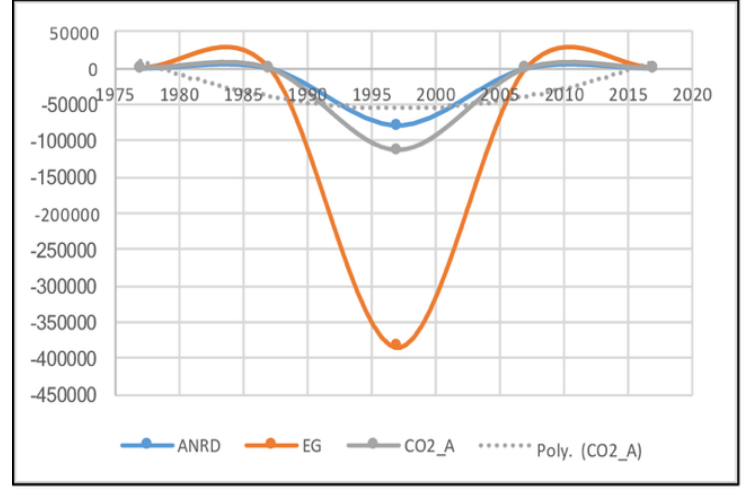

Kazakhstan consumption

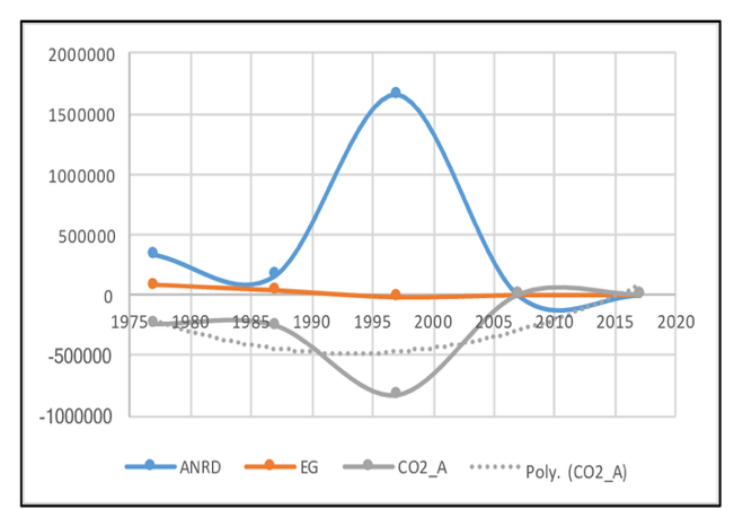

Spain consumption

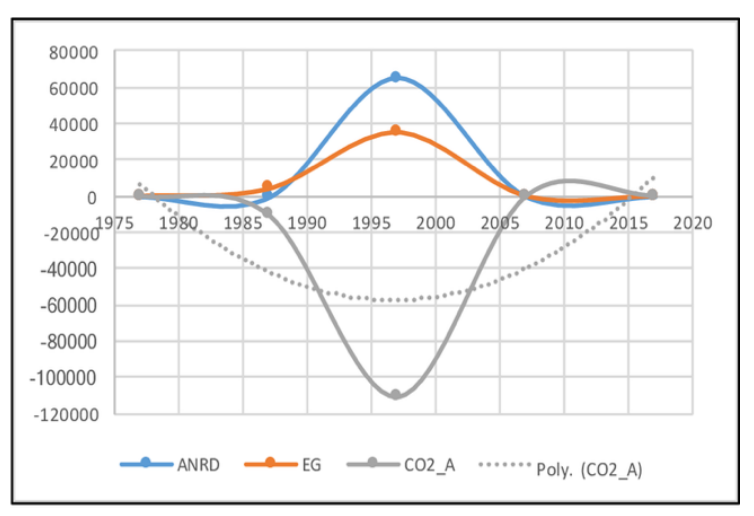

Malaysia consumption 


\begin{tabular}{|c|c|c|c|c|c|c|}
\hline Group A [t-test] & ANRD (-1) & ANRD (-2) & EG (-1) & EG (-2) & CO2_A (-1) & CO2_A (-2) \\
\hline ANRD & $0.841[25.502]$ & $0.072[2.206]$ & $0.000[-0.032]$ & $0.000[-0.003]$ & $0.000[0.796]$ & $0.000[-0.821]$ \\
\hline EG & $3.676[1.525]$ & $3.525[1.470]$ & $1.028[27.910]$ & $-0.028[-0.763]$ & $0.000[2.291]$ & $0.000[-2.311]$ \\
\hline CO2_A & $(755.402)[-0.767]$ & $1446.458[1.475]$ & $(81.432)[-5.407]$ & $77.684[5.110]$ & $1.700[58.061]$ & $(0.692)[-22.764]$ \\
\hline Group B [t-test] & NGR (-1) & NGR (-2) & EPNG (-1) & EPNG (-2) & CO2_B (-1) & CO2_B (-2) \\
\hline NGR & $1.029[30.557]$ & $(0.128)$ [-3.739] & $(0.002)$ [-0.660] & $0.004[1.312]$ & $0.000[2.103]$ & $0.000[-2.019]$ \\
\hline EPNG & $0.317[0.852]$ & $(0.406)$ [-1.073] & $1.150[33.597]$ & $(0.154)[-4.444]$ & $0.000[-0.010]$ & $0.000[-0.032]$ \\
\hline CO2_B & $(2363.177)[-1.640]$ & $2431.678[1.664]$ & $176.159[1.331]$ & (157.399) [-1.174] & $1.133[32.576]$ & $(0.129)$ [-3.695] \\
\hline Group C [t-test] & CR (-1) & CR (-2) & EPCS (-1) & EPCS (-2) & CO2_C (-1) & CO2_C (-2) \\
\hline CR & $0.670[20.059]$ & $0.142[4.279]$ & $(0.001)$ [-0.217] & $0.005[0.774]$ & $0.000[0.964]$ & $0.000[-0.979]$ \\
\hline EPCS & $0.039[0.211]$ & $0.261[1.437]$ & $0.990[29.446]$ & $(0.004)$ [-0.105] & $0.000[0.093]$ & $0.000[-0.091]$ \\
\hline $\mathrm{CO} 2 \mathrm{C}$ & $(2224.419)[-0.828]$ & $3786.855[1.421]$ & $(1644.893)[-3.335]$ & 1645.273[3.355] & $1.676[58.142]$ & $(0.666)$ [-21.959] \\
\hline Group D [t-test] & ANE (-1) & ANE (-2) & EPNS (-1) & EPNS (-2) & TGGE (-1) & TGGE (-2) \\
\hline ANE & $0.977[17.483]$ & $0.016[0.276]$ & $0.164[5.353]$ & $(0.155)$ [-5.043] & $0.000[0.400]$ & $0.000[-0.332]$ \\
\hline EPNS & $0.087[0.871]$ & $(0.099)$ [-0.980] & $1.284[23.492]$ & $(0.277)[-5.032]$ & $0.000[-0.071]$ & $0.000[0.106]$ \\
\hline TGGE & (19665.7) [-1.065] & $22779.000[1.226]$ & $8362.019[0.828]$ & $(10844.630)[-1.066]$ & $0.696[21.843]$ & $0.333[10.166]$ \\
\hline Group E [t-test] & EPOGC (-1) & EPOGC (-2) & $\mathrm{AE}(-1)$ & $\mathrm{AE}(-2)$ & CO2_INT (-1) & CO2_INT (-2) \\
\hline EPOGC & $0.924[17.984]$ & $0.077[1.483]$ & $(0.054)$ [-0.725] & $0.050[0.702]$ & $1.602[1.263]$ & $(1.967)$ [-1.553] \\
\hline $\mathbf{A E}$ & $0.036[1.478]$ & $(0.023)[-0.963]$ & $0.529[15.075]$ & $0.404[12.162]$ & $0.112[0.187]$ & $(0.716)$ [-1.207] \\
\hline CO2_INT & $(0.001)[-0.565]$ & $0.002[0.795]$ & $(0.003)$ [-1.097] & $0.003[0.961]$ & $0.866[17.336]$ & $0.096[1.934]$ \\
\hline Group F [t-test] & ANSE (-1) & ANSE (-2) & CRW (-1) & CRW (-2) & CO_F (-1) & CO_F (-2) \\
\hline ANSE & $0.840[18.716]$ & $0.027[0.631]$ & $(0.394)[-1.751]$ & $0.378[1.716]$ & $0.116[1.785]$ & $(0.048)$ [-0.754] \\
\hline CRW & $0.006[0.747]$ & $(0.014)[-1.678]$ & $1.160[25.769]$ & $(0.179)[-4.068]$ & $(0.022)[-1.741]$ & $0.012[0.975]$ \\
\hline CO_F & $(0.026)[-0.877]$ & $0.031[1.067]$ & $(0.131)$ [-0.859] & $0.142[0.948]$ & $0.764[17.195]$ & $0.199[4.554]$ \\
\hline
\end{tabular}

Table 5: Estimation by VAR

Sources: Reckoning by authors. Variable's definition indicated in Table 3. VAR estimation were estimated with individual group restrictions and provide first lag coefficients of each group with t-test. 
Table 6:Pairwise Granger Causality Test

\begin{tabular}{|c|c|c|}
\hline Distribution & Null Hypothesis & F-Statistics \\
\hline \multirow{6}{*}{$\begin{array}{c}\text { Energy } \\
\text { consumption }\end{array}$} & EG does not Granger Cause CO2_A & $22.529^{* * *}$ \\
\hline & CO2_A does not Granger Cause EG & $2.026^{*}$ \\
\hline & ANRD does not Granger Cause CO2_A & $0.695^{*}$ \\
\hline & CO2_A does not Granger Cause ANRD & $1.098^{*}$ \\
\hline & ANRD does not Granger Cause EG & $25.303^{* * *}$ \\
\hline & EG does not Granger Cause ANRD & $0.899^{*}$ \\
\hline \multirow{6}{*}{$\begin{array}{r}\text { Natural gas } \\
\text { consumption }\end{array}$} & EPNG does not Granger Cause CO2_B & $1.486^{*}$ \\
\hline & CO2_B does not Granger Cause EPNG & $0.576^{*}$ \\
\hline & NGR does not Granger Cause CO2_B & $1.478^{*}$ \\
\hline & CO2_B does not Granger Cause NGR & $4.00^{* * *}$ \\
\hline & NGR does not Granger Cause EPNG & $0.820^{*}$ \\
\hline & EPNG does not Granger Cause NGR & $8.860^{* * *}$ \\
\hline \multirow{6}{*}{$\begin{array}{c}\text { Coal rent } \\
\text { consumption }\end{array}$} & EPCS does not Granger Cause CO2_C & $5.198^{* * *}$ \\
\hline & CO2_C does not Granger Cause EPCS & $0.101^{*}$ \\
\hline & CR does not Granger Cause CO2_C & $1.214^{*}$ \\
\hline & CO2_C does not Granger Cause CR & $0.508^{*}$ \\
\hline & CR does not Granger Cause EPCS & $3.583^{* * *}$ \\
\hline & EPCS does not Granger Cause CR & $12.524^{* * *}$ \\
\hline \multirow{6}{*}{$\begin{array}{l}\text { Nuclear energy } \\
\text { consumption }\end{array}$} & EPNS does not Granger Cause TGGE & $1.516^{*}$ \\
\hline & TGGE does not Granger Cause EPNS & $0.059^{*}$ \\
\hline & ANE does not Granger Cause TGGE & $0.94^{*}$ \\
\hline & TGGE does not Granger Cause ANE & $0.280^{*}$ \\
\hline & ANE does not Granger Cause EPNS & $0.392^{*}$ \\
\hline & EPNS does not Granger Cause ANE & $16.941^{* * *}$ \\
\hline \multirow{6}{*}{$\begin{array}{l}\text { Oil, Gas and Coal } \\
\text { consumption }\end{array}$} & AE does not Granger Cause CO2_INT & $1.031^{* * *}$ \\
\hline & CO2_INT does not Granger Cause AE & $1.802^{*}$ \\
\hline & EPOGC does not Granger Cause CO2_INT & $14.266^{* * *}$ \\
\hline & CO2_INT does not Granger Cause EPOGC & $0.648^{*}$ \\
\hline & EPOGC does not Granger Cause AE & $2.659^{* *}$ \\
\hline & AE does not Granger Cause EPOGC & $0.161^{*}$ \\
\hline \multirow{6}{*}{$\begin{array}{l}\text { Renewable Energy } \\
\text { consumption }\end{array}$} & CRW does not Granger Cause CO2_F & $2.492^{*}$ \\
\hline & CO2_F does not Granger Cause CRW & $0.756^{*}$ \\
\hline & ANSE does not Granger Cause CO2_F & $0.655^{*}$ \\
\hline & CO2_F does not Granger Cause ANSE & $7.376^{* * *}$ \\
\hline & ANSE does not Granger Cause CRW & $7.148^{* * *}$ \\
\hline & CRW does not Granger Cause ANSE & $3.148^{* * *}$ \\
\hline
\end{tabular}

Sources: Reckoning by authors. Variable's definition indicated in Table $3{ }^{* * *}$ specifies the significance levels at $1 \%{ }^{* *}$ specifies the significance levels at $5 \%$ * specifies the significance levels at 10 
Table 7: Covariance of GLM by GDPG

\begin{tabular}{|c|c|c|c|c|c|c|c|c|c|c|c|c|}
\hline \multirow{2}{*}{$\begin{array}{l}\text { Variable } \\
\text { s } \\
\text { Cov. } \\
\end{array}$} & \multicolumn{2}{|c|}{ GDPG } & \multicolumn{2}{|c|}{ CO2_A } & \multicolumn{2}{|c|}{$\mathrm{CO} 2 \_\mathrm{B}$} & \multicolumn{2}{|c|}{ CO2_C } & \multicolumn{2}{|c|}{ TGGE } & \multicolumn{2}{|c|}{ CO2_INT } \\
\hline & Ordinary & $\begin{array}{l}\text { Huber- } \\
\text { White }\end{array}$ & Ordinary & $\begin{array}{l}\text { Huber- } \\
\text { White }\end{array}$ & Ordinary & $\begin{array}{l}\text { Huber- } \\
\text { White }\end{array}$ & Ordinary & $\begin{array}{l}\text { Huber- } \\
\text { White }\end{array}$ & Ordinary & $\begin{array}{l}\text { Huber- } \\
\text { White }\end{array}$ & Ordinary & $\begin{array}{l}\text { Huber- } \\
\text { White }\end{array}$ \\
\hline GDPG & & & $(2.238)^{* * *}$ & $(-1.836)^{* *}$ & $(0.436)^{* * *}$ & $(0.344)^{* *}$ & $2.277^{* * *}$ & $1.978^{* * *}$ & $2.435^{* * *}$ & $2.586^{* * *}$ & $2.953^{* * *}$ & $1.177^{* *}$ \\
\hline CO2_A & $(2.239)^{* * *}$ & $(1.913)^{* * *}$ & & & $32.626^{* * *}$ & $21.572^{* * *}$ & $36.245^{* * *}$ & $17.555^{* * *}$ & $11.833^{* * *}$ & $14.330^{* * *}$ & $2.681^{* * *}$ & $4.200^{* * *}$ \\
\hline CO2_B & $(0.437)^{* *}$ & $(0.341)^{* *}$ & $32.620^{* * *}$ & $15.149^{* * *}$ & & & $(46.465)^{* * *}$ & $(19.122)^{* * *}$ & $6.660^{* * *}$ & $7.531^{* * *}$ & $1.295^{* *}$ & $2.610^{* * *}$ \\
\hline $\mathrm{CO} 2 \_\mathrm{C}$ & $2.277^{* * *}$ & $2.052^{* * *}$ & $36.245^{* * *}$ & $18.615^{* * *}$ & $\begin{array}{c}(46.465)^{* *} \\
*\end{array}$ & $(43.388)^{* * *}$ & & & $7.438^{* * *}$ & $8.589^{* * *}$ & $3.591^{* * *}$ & $6.936^{* * *}$ \\
\hline TGGE & $2.243^{* * *}$ & $2.535^{* * *}$ & $11.833^{* * *}$ & $5.624^{* * *}$ & $6.660^{* * *}$ & $3.778^{* * *}$ & $7.438^{* * *}$ & $4.283^{* * *}$ & & & $(9.354)^{* * *}$ & $(7.431)^{* * *}$ \\
\hline $\begin{array}{l}\text { CO2_IN } \\
T\end{array}$ & $2.954^{* * *}$ & $1.414^{* *}$ & $11.833^{* * *}$ & $3.908^{* * *}$ & $1.295^{* *}$ & $1.812^{* * *}$ & $3.591^{* * *}$ & $3.119^{* * *}$ & $(9.354)^{* * *}$ & $(4.788)^{* * *}$ & & \\
\hline $\mathrm{CO} 2 \mathrm{~F}$ & $1.604^{* *}$ & $1.558^{* *}$ & $2.681^{* * *}$ & $0.244^{* *}$ & $\begin{array}{c}(10.871)^{* *} \\
*\end{array}$ & $(-8.406)^{* * *}$ & $(2.592)^{* * *}$ & $(2.626)^{* * *}$ & $7.546^{* * *}$ & $10.040^{* * *}$ & $(0.529)^{* * *}$ & $(0.574)^{* *}$ \\
\hline
\end{tabular}

Note: Variable's definition indicated in Table $3^{* * *}$ specifies the significance levels at $1 \%$ ** specifies the significance levels at $5 \%{ }^{*}$ specifies the significance levels at $10 \%$. Sources: Reckoning by authors

Table 8: Padroni Residual Co-integration Modified table by Weighted level

\begin{tabular}{|c|c|c|c|c|c|}
\hline Distribution & Dimensions & Panel v-Statistic & Panel rho-Statistic & Panel PP-Statistic & Panel ADF-Statistic \\
\hline \multirow{2}{*}{ Energy consumption } & Within & $5.283^{* * *}$ & $(1.833)^{* * *}$ & $(4.157)^{* * *}$ & $(1.744)^{* * *}$ \\
\hline & Between & & $0.224^{* *}$ & $(3.088)^{* * *}$ & $(1.595)^{* * *}$ \\
\hline \multirow{2}{*}{$\begin{array}{l}\text { Natural gas } \\
\text { consumption }\end{array}$} & Within & $1.749^{* *}$ & $1.711^{* *}$ & $1.199^{* *}$ & $2.562^{* *}$ \\
\hline & Between & & $1.262^{* *}$ & $(0.851)^{* *}$ & $1.103^{* *}$ \\
\hline \multirow{2}{*}{$\begin{array}{c}\text { Coal rent } \\
\text { consumption }\end{array}$} & Within & $(0.291)^{* *}$ & $2.488^{* *}$ & $(0.433)^{* *}$ & $2.41^{* *}$ \\
\hline & Between & & $0.373^{* *}$ & $(2.122)^{* * *}$ & $(0.148)^{* *}$ \\
\hline \multirow{2}{*}{$\begin{array}{c}\text { Nuclear energy } \\
\text { consumption }\end{array}$} & Within & $5.562^{* * *}$ & $(1.261)^{* *}$ & $(4.168)^{* * *}$ & $(2.712)^{* * *}$ \\
\hline & Between & & $0.028^{* *}$ & $(4.701)^{* * *}$ & $(1.761)^{* * *}$ \\
\hline \multirow{2}{*}{$\begin{array}{l}\text { Oil, Gas and Coal } \\
\text { consumption }\end{array}$} & Within & $(1.705)^{* *}$ & $0.192^{* *}$ & $(2.803)^{* * *}$ & $(4.354)^{* * *}$ \\
\hline & Between & & $1.027^{* *}$ & $(2.716)^{* * *}$ & $(1.284)^{* * *}$ \\
\hline \multirow{2}{*}{$\begin{array}{l}\text { Renewable energy } \\
\text { consumption }\end{array}$} & Within & $(2.366)^{* *}$ & $1.191^{* *}$ & $(3.486)^{* * *}$ & $(0.250)^{* *}$ \\
\hline & Between & & $1.329 * *$ & $(4.620)^{* * *}$ & $(1.905)^{* * *}$ \\
\hline
\end{tabular}

Note: Variable's definition indicated in Table $3{ }^{* * *}$ specifies the significance levels at $1 \%{ }^{* *}$ specifies the significance levels at $5 \% *$ specifies the significance levels at $10 \%$. Sources: Reckoning by authors 
$\mathrm{CO}_{-} \mathrm{A}$
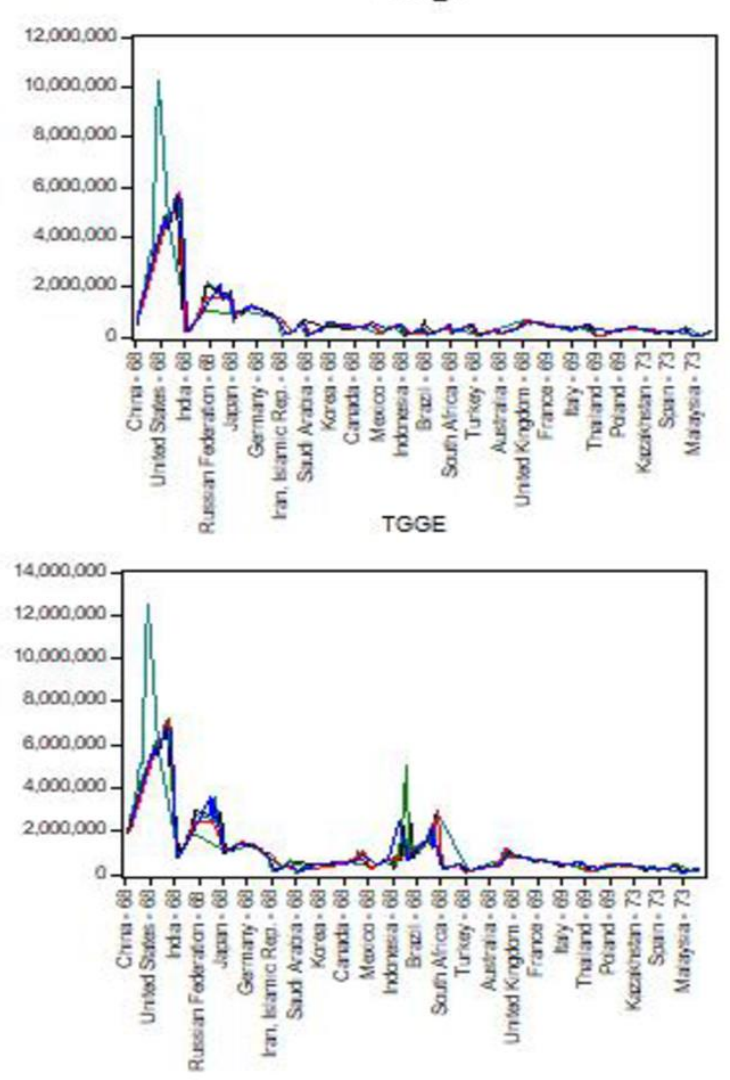

$\mathrm{CO}_{-} \mathrm{B}$
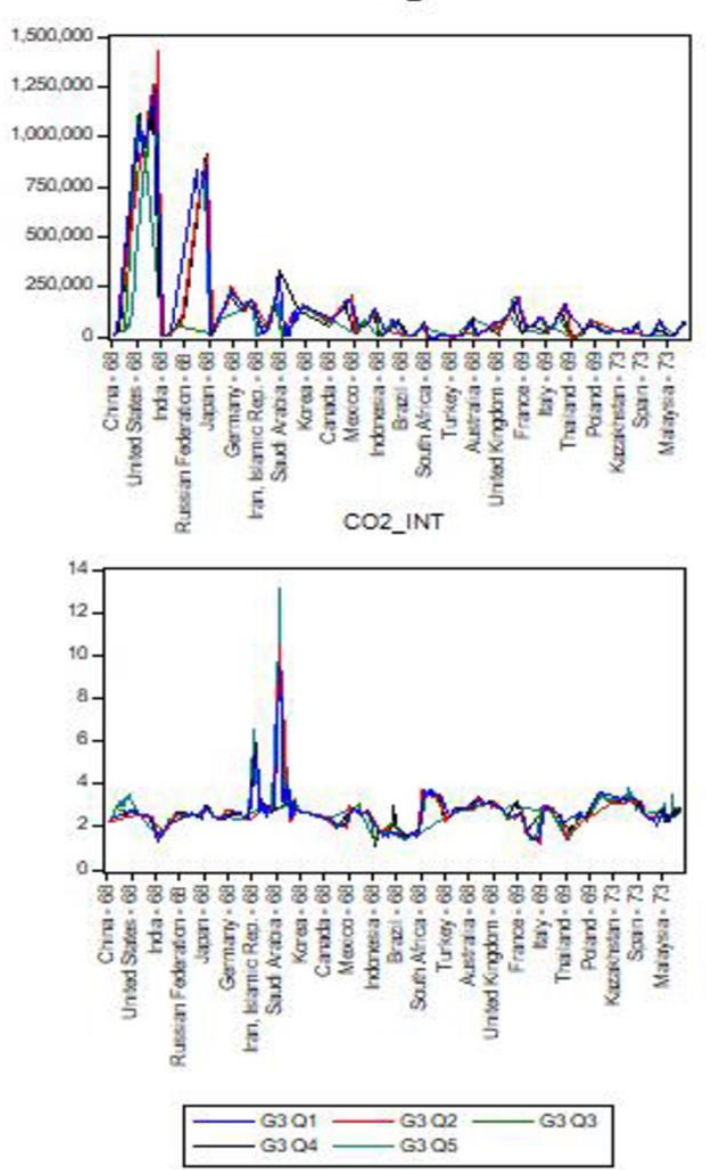

$\mathrm{CO}_{-} \mathrm{C}$
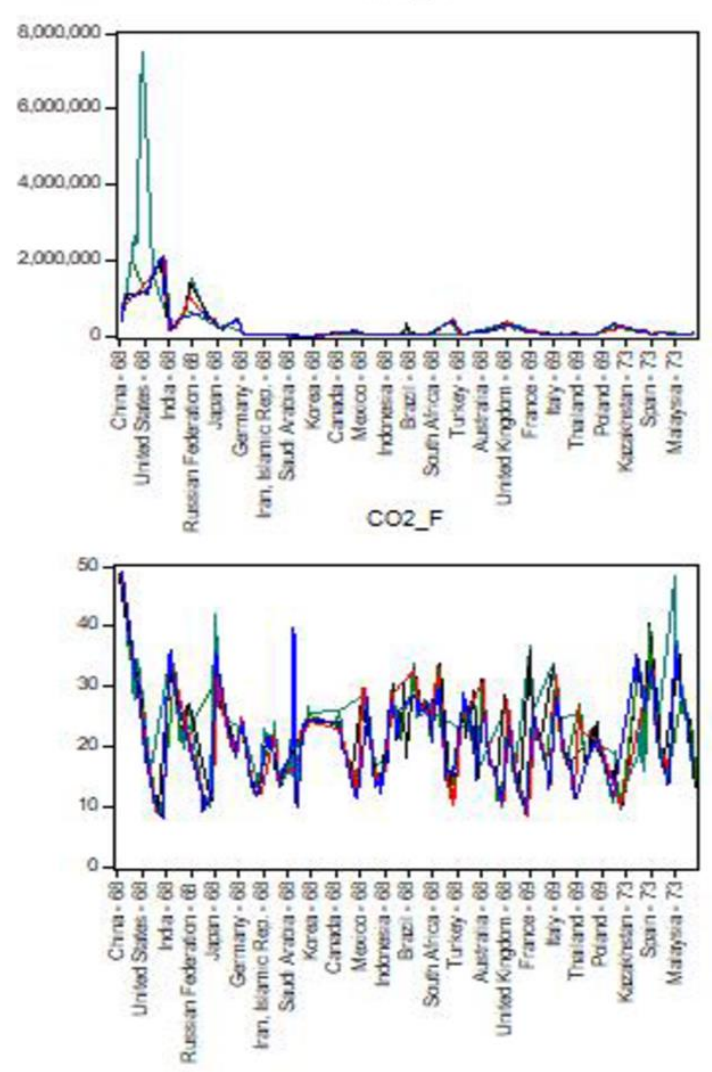
Table 9: Covariance of GLM by groups

\begin{tabular}{|c|c|c|c|c|c|c|c|}
\hline \multirow{2}{*}{$\begin{array}{l}\text { Variables } \\
\text { Covariance }\end{array}$} & \multicolumn{2}{|c|}{ ANRD } & \multicolumn{2}{|c|}{ EG } & \multicolumn{2}{|c|}{ CO2_A } & \multirow{2}{*}{ Wald-test } \\
\hline & Ordinary & Huber-White & Ordinary & Huber-White & Ordinary & Huber-White & \\
\hline ANRD & & & $(1.114)^{* *}$ & $(1.1318)^{* *}$ & $(2.253)^{* * *}$ & $(4.949)^{* * *}$ & $2.831^{* * *}$ \\
\hline EG & $(1.114)^{* *}$ & $(1.318)^{* * *}$ & & & $11.248^{* * *}$ & $7.896^{* * *}$ & $(2.253)^{* * *}$ \\
\hline \multirow[t]{2}{*}{ CO2_A } & $(2.253)^{* * *}$ & $(3.752)^{* * *}$ & $11.248^{* * *}$ & $6.047^{* * *}$ & & & $11.248^{* * *}$ \\
\hline & \multicolumn{2}{|c|}{ NGR } & \multicolumn{2}{|c|}{ EPNG } & \multicolumn{2}{|c|}{ CO2_B } & \\
\hline NGR & & & $12.308^{* * *}$ & $7.314^{* * *}$ & $9.984^{* * *}$ & $9.381^{* * *}$ & $7.804^{* * *}$ \\
\hline EPNG & $12.308^{* * *}$ & $11.089^{* * *}$ & & & $1.228^{* *}$ & $1.986^{* * *}$ & $9.984^{* * *}$ \\
\hline \multirow[t]{2}{*}{ CO2_B } & $9.984^{* * *}$ & $4.782^{* * *}$ & $1.228^{* *}$ & $2.067^{* * *}$ & & & $1.228^{* *}$ \\
\hline & \multicolumn{2}{|c|}{ CR } & \multicolumn{2}{|c|}{ EPCS } & \multicolumn{2}{|c|}{$\mathrm{CO} 2 \_\mathrm{C}$} & \\
\hline $\mathrm{CR}$ & & & $18.697^{* * *}$ & $8.263^{* * *}$ & $3.125^{* * *}$ & $1.870^{* *}$ & $0.554^{* *}$ \\
\hline EPCS & $18.694^{* * *}$ & $12.749^{* * *}$ & & & $7.795^{* * *}$ & $7.048^{* * *}$ & $3.125^{* * *}$ \\
\hline \multirow[t]{2}{*}{ CO2_C } & $3.125^{* * *}$ & $2.038^{* * *}$ & $7.795^{* * *}$ & $6.032^{* * *}$ & & & $7.795^{* * *}$ \\
\hline & \multicolumn{2}{|c|}{ ANE } & \multicolumn{2}{|c|}{ EPNS } & \multicolumn{2}{|c|}{ TGGE } & \\
\hline ANE & & & $69.596^{* * *}$ & $47.339^{* * *}$ & $(2.535)^{* * *}$ & $(4.198)^{* * *}$ & $16.684^{* * *}$ \\
\hline EPNS & $69.596^{* * *}$ & $77.593^{* * *}$ & & & $3.145^{* * *}$ & $4.512^{* * *}$ & $(2.535)^{* * *}$ \\
\hline \multirow[t]{2}{*}{ TGGE } & $(2.535)^{* * *}$ & $(4.485)^{* * *}$ & $3.145^{* * *}$ & $4.706^{* * *}$ & & & $3.145^{* * *}$ \\
\hline & \multicolumn{2}{|c|}{ EPOGC } & \multicolumn{2}{|c|}{$\mathrm{AE}$} & \multicolumn{2}{|c|}{ CO2_INT } & \\
\hline EPOGC & & & $(0.358)^{* *}$ & $(0.173)^{* *}$ & $24.442^{* * *}$ & $23.864^{* * *}$ & $11.681^{* * *}$ \\
\hline $\mathrm{AE}$ & $(0.358)^{* *}$ & $(0.143)^{* *}$ & & & $(0.913)^{* *}$ & $(0.353)^{* *}$ & $24.442^{* * *}$ \\
\hline \multirow[t]{2}{*}{ CO2_INT } & $24.442^{* * *}$ & $19.584^{* * *}$ & $(0.913)^{* *}$ & $(0.347)^{* * *}$ & & & $(0.913)^{* *}$ \\
\hline & \multicolumn{2}{|c|}{ ANSE } & \multicolumn{2}{|c|}{ CRW } & \multicolumn{2}{|c|}{ CO2_F } & \\
\hline ANSE & & & $1.360^{* *}$ & $1.060^{* * *}$ & $8.198^{* * *}$ & $5.659 * * *$ & $36.042^{* * *}$ \\
\hline CRW & $1.360^{* *}$ & $1.041^{* *}$ & & & $10.542^{* * *}$ & $11.380^{* * *}$ & $8.198^{* * *}$ \\
\hline CO2_F & $8.198^{* * *}$ & $5.516^{* * *}$ & $10.542^{* * *}$ & $9.354^{* * *}$ & & & $10.542^{* * *}$ \\
\hline
\end{tabular}

Note: Variable's definition indicated in Table $3^{* * *}$ specifies the significance levels at $1 \%{ }^{* *}$ specifies the significance levels at $5 \%$ * specifies the significance levels at $10 \%$. Sources: Reckoning by authors 


\begin{tabular}{|c|c|c|c|c|c|c|}
\hline & \multirow{3}{*}{ Variables } & \multicolumn{5}{|c|}{ Periods } \\
\hline & & $1^{\text {st }}$ & $2^{\text {nd }}$ & $3^{\text {rd }}$ & $4^{\text {th }}$ & $5^{\text {th }}$ \\
\hline & & 1968-1977 & 1978-1987 & 1988-1997 & 1998-2007 & 2008-2017 \\
\hline \multirow{2}{*}{$\begin{array}{c}\text { Energy } \\
\text { consumption }\end{array}$} & EG & $3.332^{* * *}$ & $(0.631)^{* *}$ & $(0.628)^{* *}$ & $0.610^{* *}$ & $(2.124)^{* * *}$ \\
\hline & CO2_A & $(0.933)^{* *}$ & $2.997^{* * *}$ & $3.161^{* * *}$ & $6.277^{* * *}$ & $6.318^{* * *}$ \\
\hline \multirow{2}{*}{$\begin{array}{l}\text { Natural gas } \\
\text { consumption }\end{array}$} & NGR & $0.502^{* *}$ & $1.789^{* *}$ & $(2.631)^{* * *}$ & $4.360^{* * *}$ & $0.784^{* *}$ \\
\hline & CO2_B & $(0.918)^{* *}$ & $1.144^{* *}$ & $(0.256)^{* *}$ & $1.557^{* *}$ & $0.848^{* *}$ \\
\hline \multirow{3}{*}{$\begin{array}{l}\text { Coal rent } \\
\text { consumption }\end{array}$} & CR & $(1.347)^{* *}$ & $(0.376)^{* *}$ & $(5.083)^{* *}$ & $1.886^{* *}$ & $0.434^{* *}$ \\
\hline & EPCS & $2.802^{* * *}$ & $1.701^{* * *}$ & $5.996^{* * *}$ & $5.834^{* * *}$ & $3.358^{* * *}$ \\
\hline & $\mathrm{CO} 2 \_\mathrm{C}$ & $0.837^{* *}$ & $2.919^{* * *}$ & $2.575^{* * *}$ & $3.947^{* * *}$ & $4.274^{* *}$ \\
\hline $\begin{array}{l}\text { Nuclear energy } \\
\text { consumption }\end{array}$ & ANE & $4.394^{* * *}$ & $1.118^{* *}$ & $1.322^{* *}$ & $1.842^{* *}$ & $0.946^{* *}$ \\
\hline \multirow{2}{*}{$\begin{array}{l}\text { Oil, Gas and } \\
\text { Coal } \\
\text { consumption }\end{array}$} & $\mathrm{AE}$ & - & - & $(1.126)^{* *}$ & $(2.845)^{* * *}$ & $(3.019)^{* * *}$ \\
\hline & C02_INT & - & - & $0.986^{* *}$ & $4.862^{* * *}$ & $3.485^{* * *}$ \\
\hline \multirow{3}{*}{$\begin{array}{l}\text { Renewable } \\
\text { energy } \\
\text { consumption }\end{array}$} & ANSE & - & - & $6.378^{* * *}$ & $(0.122)^{* *}$ & $3.568^{* * *}$ \\
\hline & CRW & - & - & $0.496^{* *}$ & $(1.436)^{* *}$ & $1.359^{* *}$ \\
\hline & $\mathrm{CO} 2 \_\mathrm{F}$ & - & - & $1.109^{* *}$ & $7.257^{* * *}$ & $0.974^{* *}$ \\
\hline
\end{tabular}

Note: Variable's definition indicated in Table $3^{* * *}$ specifies the significance levels at $1 \%{ }^{* *}$ specifies the significance levels at $5 \%$ * specifies the significance levels at $10 \%$. Sources: Reckoning by authors 
- Australia

- Canada

$\times$ France

- India

4 Iran, Islamic Rep.

$\checkmark$ Japan Korea

(1) Mexico

$\times$ Russian Federation

- South Africa

- Thailand

- United Kinadom

- Brazil

* China

+ Germany

- Indonesia

$\triangle$ Italy

$\nabla$ Kazakhstan

- Malaysia

* Poland

+ Saudi Arabia

- Spain

$\triangle$ Turkey

$\nabla$ United States
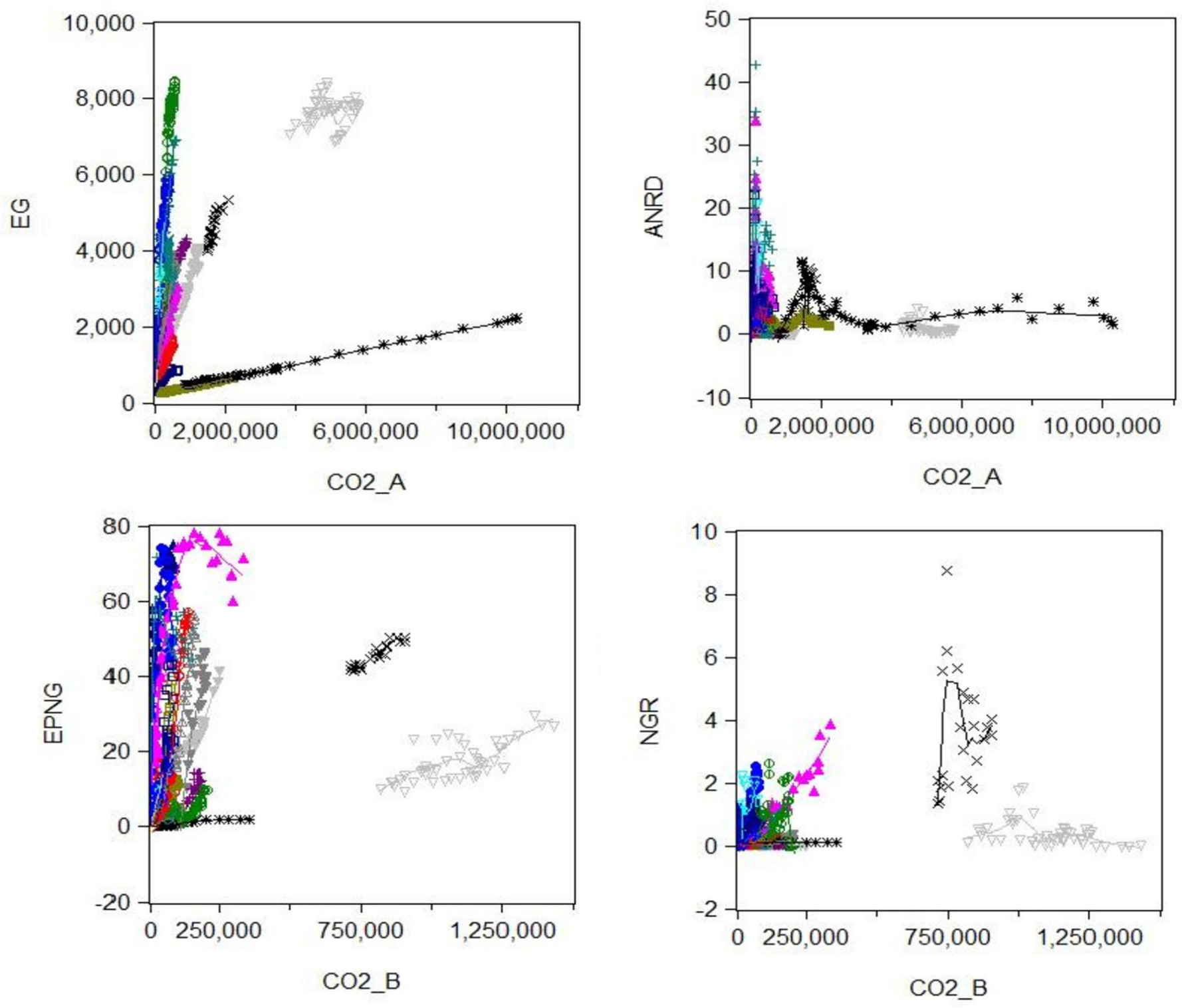

Figure 8: Group A \& B 
Table 11: Correlation

\begin{tabular}{|c|c|c|c|c|c|c|c|c|c|c|c|c|c|c|c|c|c|c|c|c|c|}
\hline Cor. & ANRD & EG & CO2_A & NGR & EPNG & $\mathrm{CO2} \_\mathrm{B}$ & CR & EPCS & $\mathrm{CO2} \_\mathrm{C}$ & ANE & EPNS & TGGE & EPOGC & $\mathbf{A E}$ & C02_INT & ANSE & CRW & CO2_F & PT & GDP & GDPG \\
\hline ANRD & 1.000 & & & & & & & & & & & & & & & & & & & & \\
\hline EG & -0.058 & 1.000 & & & & & & & & & & & & & & & & & & & \\
\hline $\mathrm{CO} 2 \_\mathrm{A}$ & -0.049 & 0.222 & 1.000 & & & & & & & & & & & & & & & & & & \\
\hline NGR & 0.582 & 0.185 & 0.002 & 1.000 & & & & & & & & & & & & & & & & & \\
\hline EPNG & 0.199 & -0.069 & -0.122 & 0.337 & 1.000 & & & & & & & & & & & & & & & & \\
\hline $\mathrm{CO} 2 \_\mathrm{B}$ & 0.019 & 0.564 & 0.638 & 0.355 & 0.204 & 1.000 & & & & & & & & & & & & & & & \\
\hline CR & 0.423 & -0.133 & 0.231 & 0.119 & -0.228 & -0.077 & 1.000 & & & & & & & & & & & & & & \\
\hline EPCS & 0.079 & -0.055 & 0.260 & -0.131 & -0.412 & -0.067 & 0.553 & 1.000 & & & & & & & & & & & & & \\
\hline $\mathrm{CO} 2 \_\mathrm{C}$ & -0.003 & -0.003 & 0.925 & -0.061 & -0.210 & 0.326 & 0.370 & 0.368 & 1.000 & & & & & & & & & & & & \\
\hline ANE & -0.347 & 0.336 & -0.073 & -0.129 & -0.286 & 0.047 & -0.326 & -0.477 & -0.148 & 1.000 & & & & & & & & & & & \\
\hline EPNS & -0.319 & 0.311 & -0.022 & -0.100 & -0.209 & 0.122 & -0.284 & -0.333 & -0.116 & 0.934 & 1.000 & & & & & & & & & & \\
\hline TGGE & -0.016 & 0.132 & 0.969 & 0.041 & -0.155 & 0.600 & 0.225 & 0.228 & 0.912 & -0.101 & -0.083 & 1.000 & & & & & & & & & \\
\hline EPOGC & 0.258 & -0.230 & 0.113 & 0.067 & 0.337 & 0.008 & 0.362 & 0.631 & 0.168 & -0.828 & -0.608 & 0.058 & 1.000 & & & & & & & & \\
\hline $\mathbf{A E}$ & -0.024 & 0.474 & 0.081 & 0.091 & 0.131 & 0.208 & -0.264 & -0.250 & -0.003 & 0.271 & 0.252 & 0.001 & -0.210 & 1.000 & & & & & & & \\
\hline C02_INT & 0.275 & -0.030 & 0.208 & 0.034 & 0.000 & -0.038 & 0.481 & 0.747 & 0.315 & -0.675 & -0.528 & 0.127 & 0.790 & 0.057 & 1.000 & & & & & & \\
\hline ANSE & -0.137 & -0.204 & 0.271 & -0.177 & -0.054 & -0.179 & -0.001 & 0.003 & 0.389 & 0.019 & 0.020 & 0.290 & -0.015 & -0.187 & -0.061 & 1.000 & & & & & \\
\hline CRW & 0.020 & -0.615 & -0.059 & -0.111 & -0.163 & -0.279 & 0.131 & 0.053 & 0.051 & -0.232 & -0.319 & 0.099 & -0.009 & -0.762 & -0.319 & 0.292 & 1.000 & & & & \\
\hline CO2_F & 0.225 & -0.564 & 0.100 & -0.141 & -0.247 & -0.454 & 0.235 & 0.068 & 0.335 & -0.151 & -0.247 & 0.195 & -0.053 & -0.251 & -0.006 & 0.382 & 0.539 & 1.000 & & & \\
\hline PT & -0.013 & -0.388 & 0.594 & -0.109 & -0.240 & 0.010 & 0.322 & 0.355 & 0.737 & -0.226 & -0.210 & 0.649 & 0.166 & -0.437 & 0.147 & 0.546 & 0.519 & 0.550 & 1.000 & & \\
\hline GDP & 0.347 & -0.270 & 0.243 & 0.103 & -0.148 & -0.119 & 0.341 & 0.354 & 0.383 & -0.290 & -0.268 & 0.285 & 0.246 & -0.223 & 0.307 & 0.411 & 0.282 & 0.408 & 0.475 & 1.000 & \\
\hline GDPG & 0.323 & -0.250 & 0.253 & 0.138 & -0.138 & -0.091 & 0.316 & 0.361 & 0.388 & -0.257 & -0.218 & 0.284 & 0.247 & -0.135 & 0.331 & 0.356 & 0.190 & 0.375 & 0.442 & $\begin{array}{l}0.980 \\
\end{array}$ & 1.000 \\
\hline
\end{tabular}

Note: Cor. is indicating Correlation. Variable's definition indicated in Table $3{ }^{* * *}$ specifies the significance levels at $1 \%{ }^{* *}$ specifies the significance levels at $5 \%$ * specifies the significance levels at $10 \%$. Sources: Reckoning by authors 
- Australia

- Canada

$\times$ France

- India

* Iran, Islamic Rep

Japan

Korea

( ) Mexico

$\times$ Russian Federation

- South Africa

- Thailand

- United Kinadom

- Brazil

* China

+ Germany

- Indonesia

$\triangle$ Italy

- Kazakhstan

- Malaysia

* Poland

+ Saudi Arabia

- Spain

$\triangle$ Turkey

United States

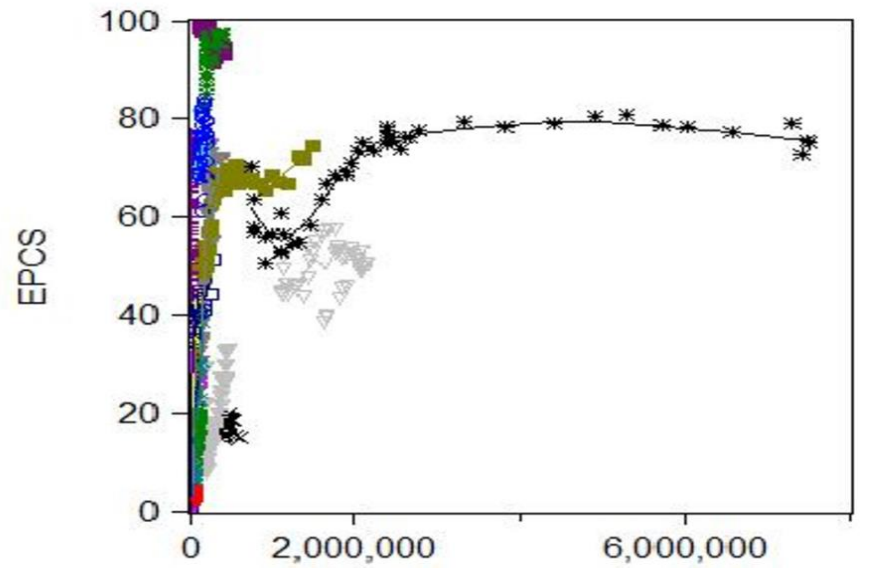

CO2_C

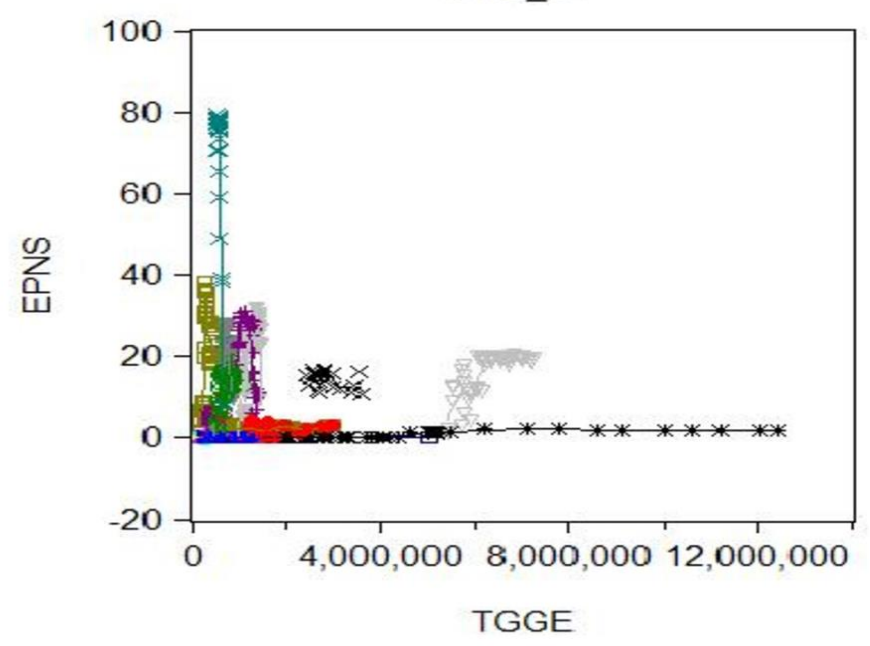

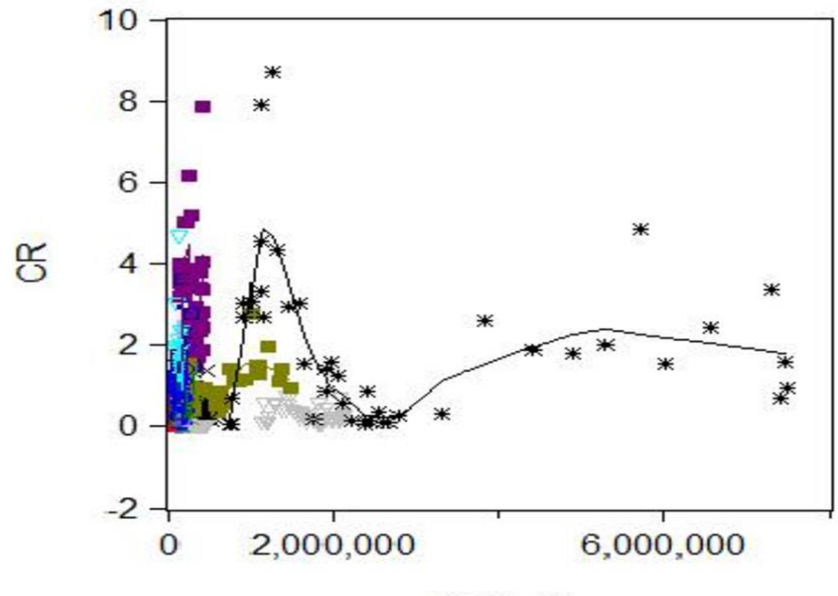

CO2_C

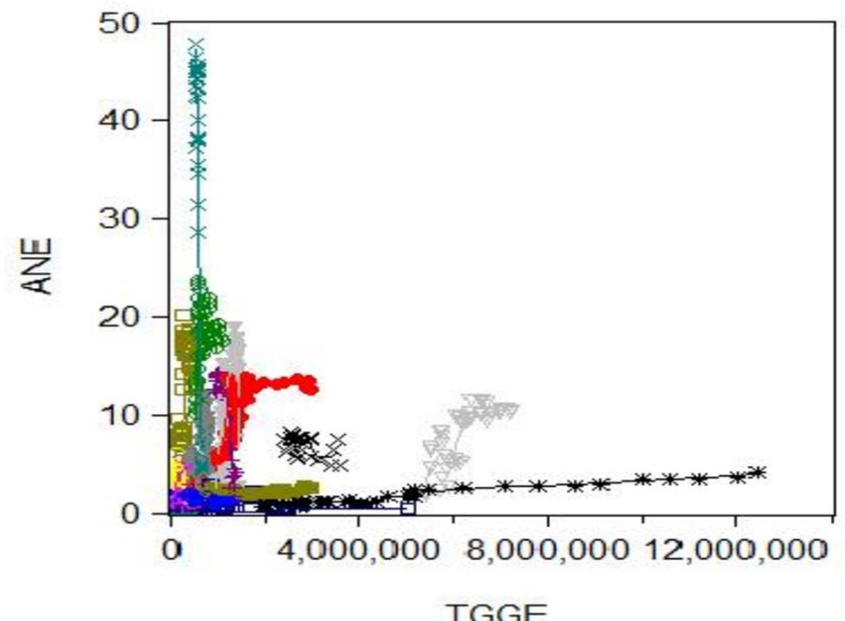


- Australia

- Canada

$\times$ France

- India

- Iran, Islamic Rep.

Japan

Korea

(1) Mexico

$\times$ Russian Federation

- South Africa

- Thailand

- United Kinadom

- Brazil

* China

+ Germany

ㅁ Indonesia

$\triangle$ Italy

$\checkmark$ Kazakhstan

- Malaysia

* Poland

+ Saudi Arabia

- Spain

$\triangle$ Turkey

United States
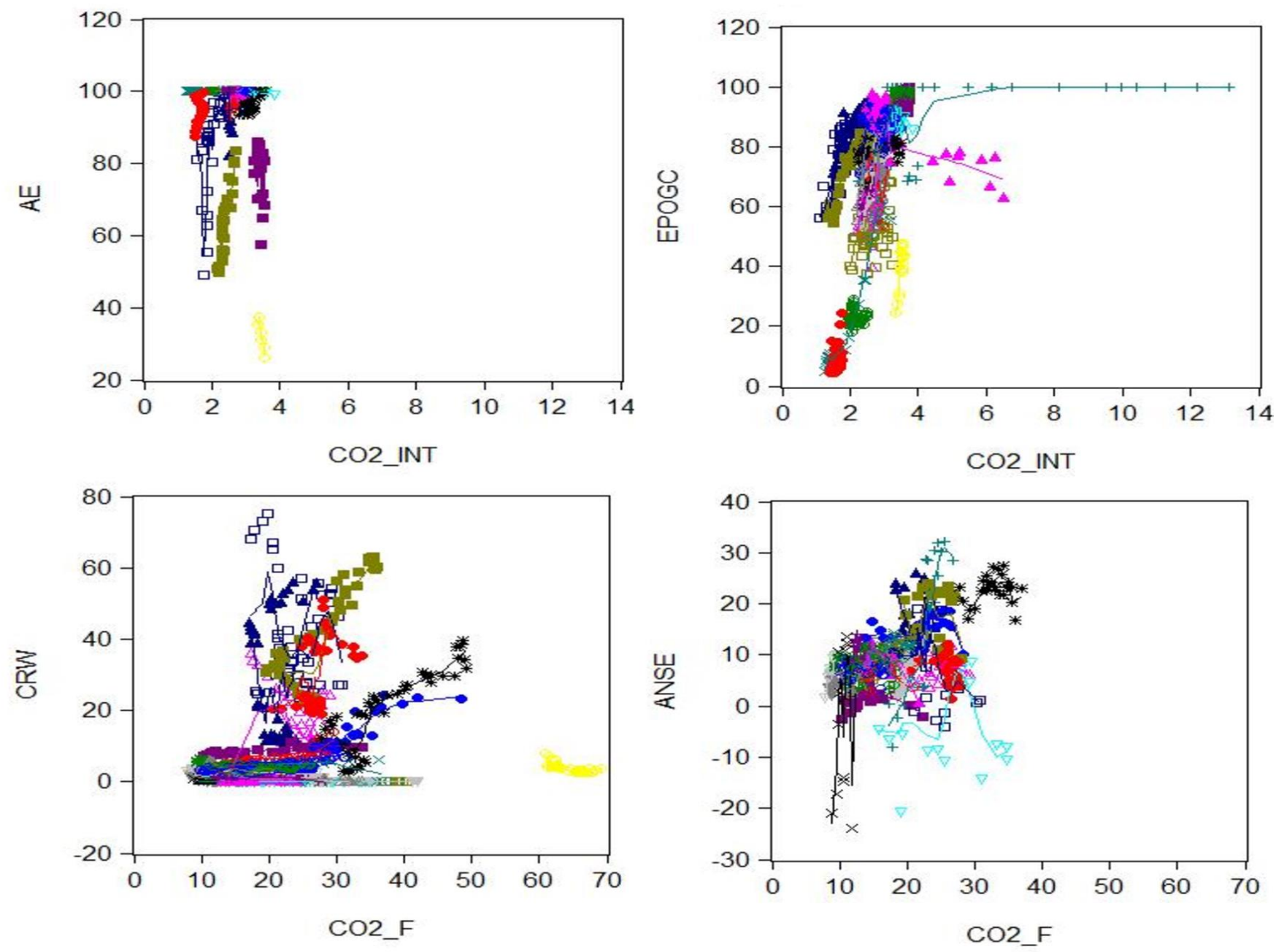

Figure 10: Group E \& F 


\section{Conclusion and policy implication}

This research study assesses the relationship of energy computation by Energy, Natural Gas, Coal Rent, Nuclear Energy, Oil Gas and Coal, Renewable Energy and its effect on GDP in the period of 1968 and 2017 using a panel data set. The co-variance of GLM and stepwise regression are applied to investigate the relationship among individual group of explanatory variables, then after the Granger causality and variance analysis are employed of the energy consumption and contribution of relevant factor of production of electricity by difference sources and intensity of $\mathrm{CO} 2$ emission in 24 highly polluted countries. It is significant that in each group there is indication for a unidirectional relationship of Granger causality found in the energy consumption. Furthermore, that ANRD, EG, NGR, EPNG, CR, EPCS, ANE, EPNS, EPOGC, AE, ANSE and CRW are not a Granger cause of CO2_A, CO2_B, CO2_C, TGGE, CO2_INT and $\mathrm{CO} 2 \mathrm{~F}$ differed from earlier study and specifies that the level of growth of energy consumption precedes in highly polluted countries, which can comprehend as a feature of economic growth. It temporarily, the results estimation also suggests that if CO2_A, CO2_B, CO2_C, TGGE, CO2_INT and $\mathrm{CO} 2$ F is mismanaged into barren economic sectors, then economic growth of individual state might be trifling or fail to occur at all. Additionally, the existence of unidirectional causality running from economic growth to energy consumption. Analysis estimation results indicate that huge production of electricity from different sources cause of $\mathrm{CO} 2$ emission and positively influence on economic growth and validity has slightly decrease after continuous increase and eventually steadies. However, a positive unidirectional causality from 24 pullulated counties energy consumption to economic development is detected, while short-run bidirectional casualty exists among above six group of variables. The above results are also indicated some valuable strategy and implication as follows.

First, energy and natural gas intake policy should be revised and modified in China, USA, India, Russia and Japan to reduce energy, natural gas and green gas consumption in $6^{\text {th }}$ (Next ten years) period and control the production of electricity by natural resources in group 1,2,3 and 4. However, the oil, gas and renewable energy consumption in Saudi Arbia, Iran, Korea and China should be modified with new equips and policies to control $\mathrm{CO} 2$ emission and production of electricity. Second, the Granger causality test results suggest that the presence of unidirectional causality from Energy, Natural Gas, Coal rent, Nuclear Energy Oil, Gas and Coal Renewable Energy consumption to economic growth. And the consequences of results impulse response, the impact of 24 top polluted countries energy consumption would at first increases than decrease and upcoming $6^{\text {th }}$ and $7^{\text {th }}$ period more stabilize with new modified strategies for control energy consumption. Third, clean energy consumption role should be endorsed and restrained in above countries, so that energy environmental quality and affordability might be enhanced and the ecosystem is secure in upcoming period. Unilateral causality is found in between energy consumption and economic growth. Therefore, consumption of energy might be conductive of 24 top polluted countries and better economic development, the consumption of energy should be facelifted and guaranteed, while the resources of countries should be limited. Thus, varying current consumption of the energy mix in above countries, likewise, endowing and impelling of clean energy is necessary for coming generation.

\section{Acknowledgement}

I really acknowledge the helpful instruction and comments from my supervisor and admiringly acknowledge the financial support of the National Natural Science Foundation of China No: 71371087 of Jiangsu University. I exceedingly appreciate my parents and family who encourage me to as a scholar and I can't ignore the value poor student who scarifies all emotions and sentiments for their bright future. In last I really recognize to be-love supporter who hold me and give me strength and power for extant and enduring. 


\section{Reference}

((Acheampong 2018) Acheampong, Alex O. 2018. Economic growth, CO2 emissions and energy consumption: What causes what and where? Energy Economics 74: 677-92. https://doi.org/10.1016/j.eneco.2018.07.022.

((Alkhathlan and Javid 2015) Alkhathlan, Khalid, and Muhammad Javid. 2015. Carbon emissions and oil consumption in Saudi Arabia. Renewable and Sustainable Energy Reviews 48: 105-11. https://doi.org/10.1016/j.rser.2015.03.072.

((Anandarajah and Gambhir 2014) Anandarajah, Gabrial, and Ajay Gambhir. 2014. India's CO2 emission pathways to 2050: What role can renewables play? Applied Energy 131: 79-86. https://doi.org/10.1016/j.apenergy.2014.06.026.

((Aydin 2019) Aydin, Mucahit. 2019. The effect of biomass energy consumption on economic growth in BRICS countries: A country-specific panel data analysis. Renewable Energy 138: 620-27. https://doi.org/10.1016/j.renene.2019.02.001.

((Baek 2017) Baek, J.Choi, Y.J. . 2017. Does Foreign Direct Investment Harm the Environment in Developing Countries? Dynamic Panel Analysis of Latin American Countries. Economies 5. https://doi.org/10.3390/economies5040039.

((Boden et al. 2011) Boden, T.A, G.Marland, and R.J.Andres. 2011. Global, Regional, and National Foossil-Fuel CO2 Emission. USA.

((Cai et al. 2018) Cai, Yifei, Chung Yan Sam, and Tsangyao Chang. 2018. Nexus between clean energy consumption, economic growth and $\mathrm{CO} 2$ emissions. Journal of Cleaner Production 182: 1001-11. https://doi.org/10.1016/j.jclepro.2018.02.035.

((Chen et al. 2019) Chen, Jindao, Qian Shi, Liyin Shen, Yao Huang, and Ya Wu. 2019. What makes the difference in construction carbon emissions between China and USA? Sustainable Cities and Society 44: 604-13. https://doi.org/10.1016/j.scs.2018.10.017.

((Cheng et al. 2019) Cheng, Cheng, Xiaohang Ren, Zhen Wang, and Cheng Yan. 2019. Heterogeneous impacts of renewable energy and environmental patents on $\mathrm{CO} 2$ emission - Evidence from the BRIICS. Science of The Total Environment 668: 1328-38.

https://doi.org/10.1016/j.scitotenv.2019.02.063.

((Cheng et al. 2017) Cheng, Zhilong, Jingyu Wang, Shangshang Wei, Zhigang Guo, Jian Yang, and Qiuwang Wang. 2017. Optimization of gaseous fuel injection for saving energy consumption and improving imbalance of heat distribution in iron ore sintering. Applied Energy 207: 230-42. https://doi.org/10.1016/j.apenergy.2017.06.024.

((Chong et al. 2019) Chong, Chin Hao, Wei Xin Tan, Zhao Jia Ting, Pei Liu, Linwei Ma, Zheng Li, and Weidou Ni. 2019. The driving factors of energy-related CO2 emission growth in Malaysia: The LMDI decomposition method based on energy allocation analysis. Renewable and Sustainable Energy Reviews 115: 109356. https://doi.org/10.1016/j.rser.2019.109356.

((Dong et al. 2019) Dong, Feng, Ying Wang, Bin Su, Yifei Hua, and Yuanqing Zhang. 2019. The process of peak $\mathrm{CO} 2$ emissions in developed economies: A perspective of industrialization and urbanization. Resources, Conservation and Recycling 141: 61-75.

https://doi.org/10.1016/j.resconrec.2018.10.010.

((Dong et al. 2018) Dong, Kangyin, Renjin Sun, and Xiucheng Dong. 2018. CO2 emissions, natural gas and renewables, economic growth: Assessing the evidence from China. Science of The Total Environment 640-641: 293-302. https://doi.org/10.1016/j.scitotenv.2018.05.322.

((Emirmahmutoglu and Kose 2011) Emirmahmutoglu, Furkan, and Nezir Kose. 2011. Testing for Granger causality in heterogeneous mixed panels. Economic Modelling 28: 870-76.

https://doi.org/10.1016/j.econmod.2010.10.018. 
((Etemad et al. 1991) Etemad, B, J.Luciani, P.Bairoch, and J.C.Toutian. 1991. World Energy Production 1800-1985. Librarie DROZ, Switzerland.

((Fadiran et al. 2019) Fadiran, Gideon, Adebisi T. Adebusuyi, and David Fadiran. 2019. Natural gas consumption and economic growth: Evidence from selected natural gas vehicle markets in Europe. Energy 169: 467-77. https://doi.org/10.1016/j.energy.2018.12.040.

((Fernández González et al. 2014) Fernández González, P., M. Landajo, and M. J. Presno. 2014. Multilevel LMDI decomposition of changes in aggregate energy consumption. A cross country analysis in the EU-27. Energy Policy 68: 576-84. https://doi.org/10.1016/j.enpol.2013.12.065.

((González et al. 2019) González, Rosa Marina, Gustavo A. Marrero, Jesús Rodríguez-López, and Ángel S. Marrero. 2019. Analyzing CO2 emissions from passenger cars in Europe: A dynamic panel data approach. Energy Policy 129: 1271-81. https://doi.org/10.1016/j.enpol.2019.03.031.

((Gupta et al. 1995) Gupta, N. C., V. K. Jain, and N. K. Bansal. 1995. CO2 reduction potential through nonconventional energy sources in India. Energy 20: 549-53. https://doi.org/10.1016/03605442(94)00093-I.

((Hao et al. 2018) Hao, Yu, Ling'ou Wang, Lingyun Zhu, and Minjie Ye. 2018. The dynamic relationship between energy consumption, investment and economic growth in China's rural area: New evidence based on provincial panel data. Energy 154: 374-82.

https://doi.org/10.1016/j.energy.2018.04.142.

((Hardin 2007 ) Hardin, James W. and Joseph M. Hilbe 2007 Generalized Linear Models and Extensions. Second ed.

((Herrerias et al. 2013) Herrerias, M. J., R. Joyeux, and E. Girardin. 2013. Short- and long-run causality between energy consumption and economic growth: Evidence across regions in China. Applied Energy 112: 1483-92. https://doi.org/10.1016/j.apenergy.2013.04.054.

((Hosseini et al. 2019) Hosseini, Seyed Mohsen, Amirali Saifoddin, Reza Shirmohammadi, and Alireza Aslani. 2019. Forecasting of $\mathrm{CO} 2$ emissions in Iran based on time series and regression analysis. Energy Reports 5: 619-31. https://doi.org/10.1016/j.egyr.2019.05.004.

((Jeong et al. 2018) Jeong, Kwangbok, Taehoon Hong, and Jimin Kim. 2018. Development of a CO2 emission benchmark for achieving the national $\mathrm{CO} 2$ emission reduction target by 2030. Energy and Buildings 158: 86-94. https://doi.org/10.1016/j.enbuild.2017.10.015.

((Jiang et al. 2018) Jiang, Xue-ting, Qiang Wang, and Rongrong Li. 2018. Investigating factors affecting carbon emission in China and the USA: A perspective of stratified heterogeneity. Journal of Cleaner Production 199: 85-92. https://doi.org/10.1016/j.jclepro.2018.07.160.

((Jin and Kim 2018) Jin, Taeyoung, and Jinsoo Kim. 2018. What is better for mitigating carbon emissions - Renewable energy or nuclear energy? A panel data analysis. Renewable and Sustainable Energy Reviews 91: 464-71. https://doi.org/10.1016/j.rser.2018.04.022.

((Kang et al. 2019) Kang, Sang Hoon, Faridul Islam, and Aviral Kumar Tiwari. 2019. The dynamic relationships among $\mathrm{CO} 2$ emissions, renewable and non-renewable energy sources, and economic growth in India: Evidence from time-varying Bayesian VAR model. Structural Change and Economic Dynamics 50: 90-101. https://doi.org/10.1016/j.strueco.2019.05.006.

((Kao C 1995) Kao C, Chen B. . 1995. On the estimation and inference of a cointegrated regression inpanel data when the cross-section and time-series dimensions are compa-rable. Syracuse University: Department of Economics, .

((Karney 2019) Karney, Daniel H. 2019. Electricity market deregulation and environmental regulation: Evidence from U.S. nuclear power. Energy Economics: 104500.

https://doi.org/10.1016/j.eneco.2019.104500.

((Ketenci 2018) Ketenci, Natalya. 2018. The environmental Kuznets curve in the case of Russia. Russian Journal of Economic 4: 249-65. 
((Kharbach and Chfadi 2018) Kharbach, Mohammed, and Tarik Chfadi. 2018. Oil prices and electricity production in Morocco. Energy Strategy Reviews 22: 320-24.

https://doi.org/10.1016/j.esr.2018.10.006.

((Kong and Khan 2019) Kong, YuSheng, and Rab Khan. 2019. To examine environmental pollution by economic growth and their impact in an environmental Kuznets curve (EKC) among developed and developing countries. PloS one 14. https://doi.org/10.1371/journal.pone.0209532.

((Kumar and Sinha 1995) Kumar, Sanjay, and S. Sinha. 1995. Non-CO2-emitting renewable energy sources in India: Paths, realisable potential and requirement of industry related forestry pattern. Energy Conversion and Management 36: 885-88. https://doi.org/10.1016/01968904(95)00145-4.

((Li et al. 2019) Li, Zhi-Guo, Han Cheng, and Tian-Yao Gu. 2019. Research on dynamic relationship between natural gas consumption and economic growth in China. Structural Change and Economic Dynamics 49: 334-39. https://doi.org/10.1016/j.strueco.2018.11.006.

((Liang et al. 2019) Liang, Ting, Jian Chai, Yue-Jun Zhang, and Zhe George Zhang. 2019. Refined analysis and prediction of natural gas consumption in China. Journal of Management Science and Engineering. https://doi.org/10.1016/j.jmse.2019.07.001.

((Lin et al. 2018) Lin, Jiang, David Fridley, Hongyou Lu, Lynn Price, and Nan Zhou. 2018. Has coal use peaked in China: Near-term trends in China's coal consumption. Energy Policy 123: 208-14. https://doi.org/10.1016/j.enpol.2018.08.058.

((McCullagh 1989) McCullagh, Peter, and J. A. Nelder. 1989. Generalized Linear Models. Second ed. London: Chapman \& Hall.

((McGee and Greiner 2019) McGee, Julius Alexander, and Patrick Trent Greiner. 2019. Renewable energy injustice: The socio-environmental implications of renewable energy consumption. Energy Research \& Social Science 56: 101214. https://doi.org/10.1016/j.erss.2019.05.024.

((Mezghani and Ben Haddad 2017) Mezghani, Imed, and Hedi Ben Haddad. 2017. Energy consumption and economic growth: An empirical study of the electricity consumption in Saudi Arabia. Renewable and Sustainable Energy Reviews 75: 145-56.

https://doi.org/10.1016/j.rser.2016.10.058.

((Morales Pedraza 2019) Morales Pedraza, Jorge. 2019. Chapter 4 - Current Status and Perspective in the Use of Coal for Electricity Generation in the North America Region. In Conventional Energy in North America. Edited by Jorge Morales Pedraza. Elsevier, pp. 211-57.

((Ohashi et al. 2017) Ohashi, Mizue, Yuko Maekawa, Yoshiaki Hashimoto, Yoko Takematsu, Sasitorn Hasin, and Seiki Yamane. 2017. CO2 emission from subterranean nests of ants and termites in a tropical rain forest in Sarawak, Malaysia. Applied Soil Ecology 117-118: 147-55.

https://doi.org/10.1016/j.apsoil.2017.04.016.

((P. 2004) P., Pedroni. 2004. Panel cointegration: Asymptotic and Finite Sample Properties of Pooled Time Series Tests with an Application to the PPP Hypothesis. Econometric theory 3: 579-625.

((Pao and Tsai 2011) Pao, Hsiao-Tien, and Chung-Ming Tsai. 2011. Multivariate Granger causality between $\mathrm{CO} 2$ emissions, energy consumption, FDI (foreign direct investment) and GDP (gross domestic product): Evidence from a panel of BRIC (Brazil, Russian Federation, India, and China) countries. Energy 36: 685-93. https://doi.org/10.1016/j.energy.2010.09.041.

((Shan et al. 2018) Shan, Yuli, Dabo Guan, Jing Meng, Zhu Liu, Heike Schroeder, Jianghua Liu, and Zhifu Mi. 2018. Rapid growth of petroleum coke consumption and its related emissions in China. Applied Energy 226: 494-502. https://doi.org/10.1016/j.apenergy.2018.06.019.

((Solaymani 2019) Solaymani, Saeed. 2019. CO2 emissions patterns in 7 top carbon emitter economies: The case of transport sector. Energy 168: 989-1001. https://doi.org/10.1016/j.energy.2018.11.145. 
((Uribe et al. 2018) Uribe, Jorge M., Montserrat Guillen, and Stephania Mosquera-López. 2018. Uncovering the nonlinear predictive causality between natural gas and electricity prices. Energy Economics 74: 904-16. https://doi.org/10.1016/j.eneco.2018.07.025.

((Valadkhani et al. 2019a) Valadkhani, Abbas, Jeremy Nguyen, and Mark Bowden. 2019a. Pathways to reduce $\mathrm{CO} 2$ emissions as countries proceed through stages of economic development. Energy Policy 129: 268-78. https://doi.org/10.1016/j.enpol.2019.02.024.

((Valadkhani et al. 2019b) Valadkhani, Abbas, Russell Smyth, and Jeremy Nguyen. 2019b. Effects of primary energy consumption on $\mathrm{CO} 2$ emissions under optimal thresholds: Evidence from sixty countries over the last half century. Energy Economics 80: 680-90. https://doi.org/10.1016/j.eneco.2019.02.010.

((Wang et al. 2019) Wang, Changbo, Lixiao Zhang, Peng Zhou, Yuan Chang, Dequn Zhou, Mingyue Pang, and Hao Yin. 2019. Assessing the environmental externalities for biomass- and coal-fired electricity generation in China: A supply chain perspective. Journal of Environmental Management 246: 758-67. https://doi.org/10.1016/j.jenvman.2019.06.047.

((Wolde-Rufael and Menyah 2010) Wolde-Rufael, Yemane, and Kojo Menyah. 2010. Nuclear energy consumption and economic growth in nine developed countries. Energy Economics 32: 550-56. https://doi.org/10.1016/j.eneco.2010.01.004.

((Xu and Lin 2019) Xu, Bin, and Boqiang Lin. 2019. Can expanding natural gas consumption reduce China's CO2 emissions? Energy Economics 81: 393-407. https://doi.org/10.1016/j.eneco.2019.04.012.

((Xu et al. 2019) Xu, Guangyue, Peter Schwarz, and Hualiu Yang. 2019. Determining China's CO2 emissions peak with a dynamic nonlinear artificial neural network approach and scenario analysis. Energy Policy 128: 752-62. https://doi.org/10.1016/j.enpol.2019.01.058.

((Xu et al. 2018) Xu, Xinwanghao, Hong Huo, Jingru Liu, Yuli Shan, Yuan Li, Heran Zheng, Dabo Guan, and Zhiyun Ouyang. 2018. Patterns of CO2 emissions in 18 central Chinese cities from 2000 to 2014. Journal of Cleaner Production 172: 529-40. https://doi.org/10.1016/j.jclepro.2017.10.136. 